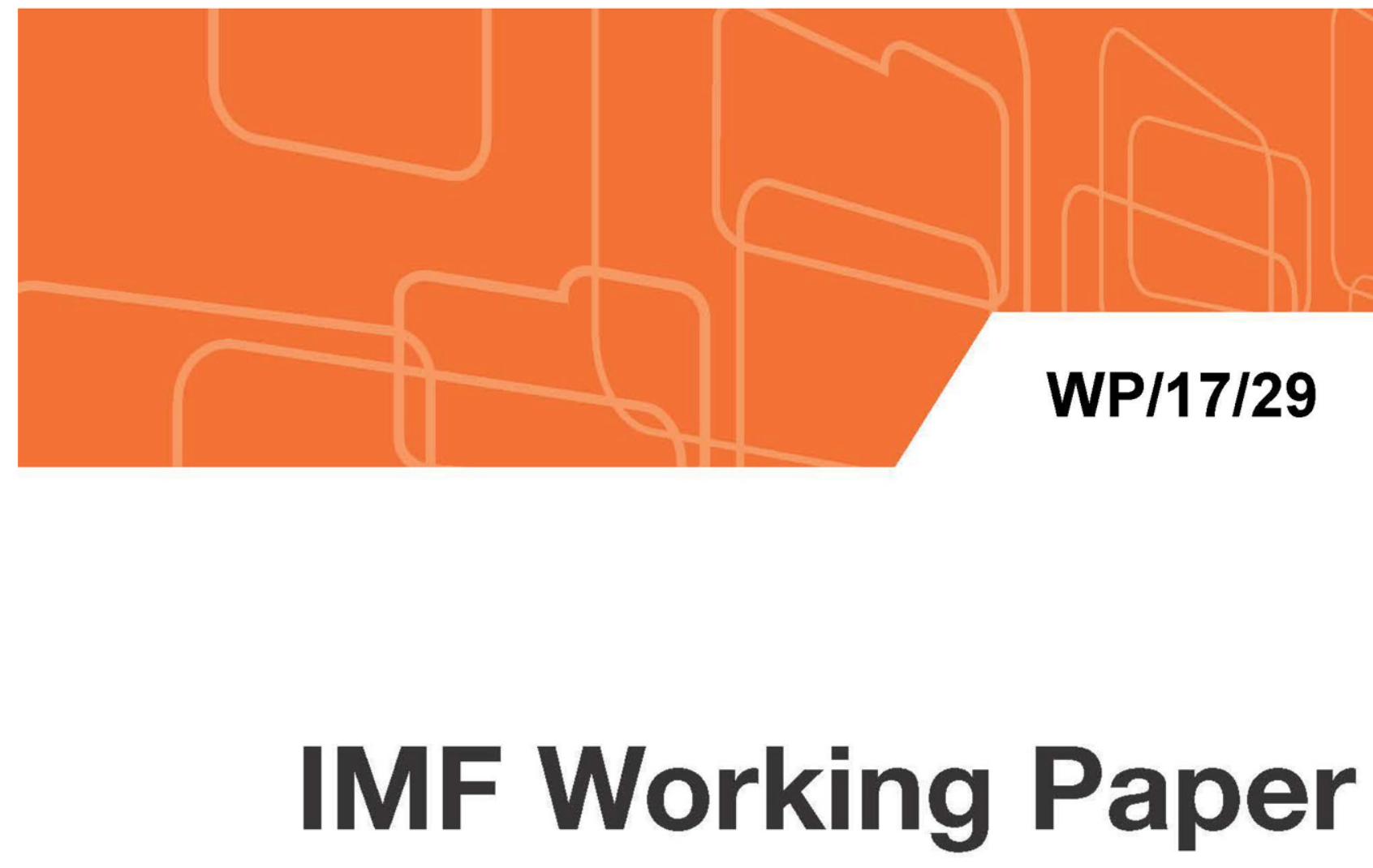

Terms-of-Trade Cycles and External Adjustment

by Gustavo Adler, Nicolas E. Magud, and Alejandro Werner 


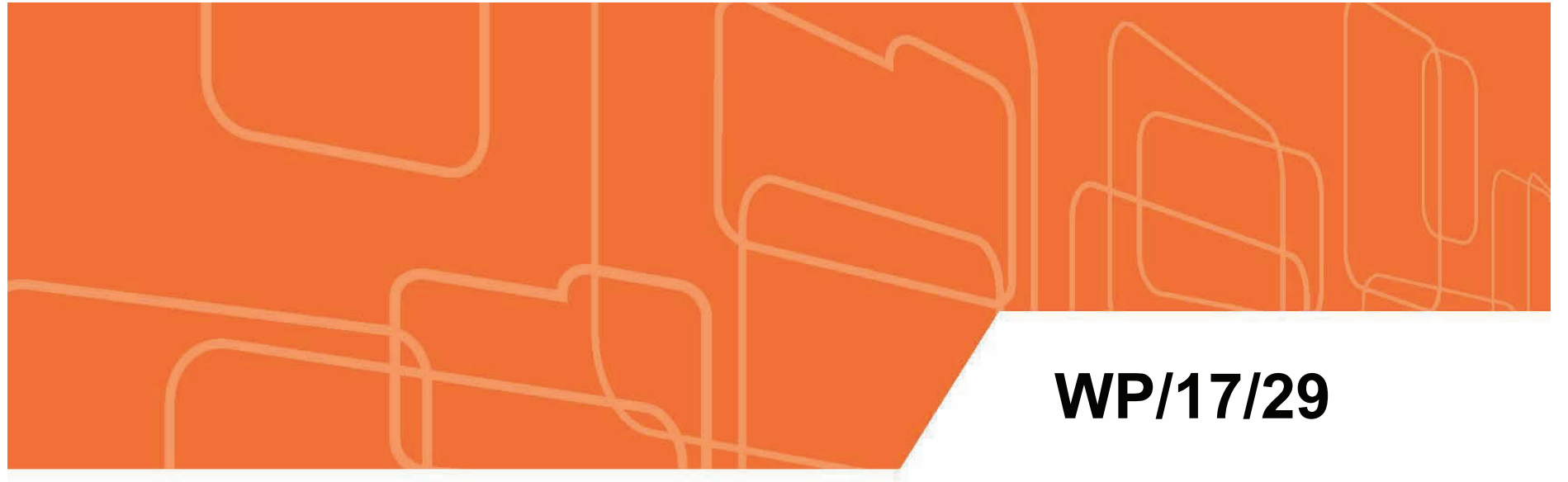

\section{IMF Working Paper}

Terms-of-Trade Cycles and External Adjustment

by Gustavo Adler, Nicolas E. Magud, and Alejandro Werner

I N T E R N A T I O N A L M O N E T A R Y F U N D 
Western Hemisphere Department

\title{
Terms-of-Trade Cycles and External Adjustment ${ }^{1}$
}

\section{Prepared by Gustavo Adler, Nicolas E. Magud, and Alejandro Werner}

Authorized for distribution by Alejandro Werner

February 2017

\section{IMF Working Papers describe research in progress by the author(s) and are published to} elicit comments and to encourage debate. The views expressed in IMF Working Papers are those of the author(s) and do not necessarily represent the views of the IMF, its Executive Board, or IMF management.

\begin{abstract}
We study the process of external adjustment to large terms-of-trade level shiftsidentified with a Markov-switching approach - for a large set of countries during the period 1960-2015. We find that adjustment to these shocks is relatively fast. Current accounts experience, on average, a contemporaneous variation of only about $1 / 2$ of the magnitude of the price shock - indicating a significant volume offset - and a full adjustment within 3-4 years. Dynamics are largely symmetric for terms-of-trade booms and busts, as well as for advanced and emerging market economies. External adjustment is driven primarily by offsetting shifts in domestic demand, as opposed to variations in output (also reflected in the response of import rather than export volumes), indicating a strong income channel at play. Exchange rate flexibility appears to have played an important buffering role during booms, but less so during busts; while international reserve holdings have been a key tool for smoothing the adjustment process.
\end{abstract}

JEL Classification Numbers: F32, F41, F44

Keywords: terms of trade; external adjustment; current account

Author’s E-Mail Address: gadler@imf.org,nmagud@,imf.org, and awerner@imf.org.

\footnotetext{
${ }^{1}$ We would like to thank Marcos Chamon, Maxym Kryshko, Nan Li, and Juan Ruiz for very useful comments; and Steve Brito, Genevieve Lindow, and Rodrigo Mariscal for their superb research assistance. Any remaining errors are ours.
} 


\section{INTRODUCTION}

The sharp drop of commodity prices in recent years has revived the discussion on the economic impact of large terms of trade (ToT) shocks and the resulting process of external adjustment. As discussed in IMF (2016), the sizable ToT fluctuations in recent years had a visible impact on current accounts of both commodity exporters and importers, but price variations were also offset by adjusting quantities in many cases, leading to limited current account variation. What determines the speed of external adjustment to large ToT shocks? What are the domestic consequences of this process - in particular, how do supply and demand (and in turn, exports and imports) respond? Is the adjustment different for advanced and emerging market economies? Do commodity exporters and importers respond differently to these shocks? What is the role of exchange rate flexibility and of the use of international reserves? Has the adjustment process in the recent episode been different from past ones? These questions are the focus of our paper.

The literature on the relationship between ToT shocks and the current account is vast, dating back to the work of Harberger (1950), Laursen and Metzler (1950), Sachs (1981), Svensson and Razin (1983), Obstfeld (1982), and Persson and Svensson (1985); and more recently the empirical work by Ostry and Reinhart (1992), Ogaki et al (1996), Cashin and McDermott (2002 and 2003); Kent and Cashin (2003), Otto (2003), and Agenor and Aizenman (2004), among others. Much of this literature focused on cyclical or temporary variations of ToT. Yet, recent movements point to structural shifts in ToT (reflecting a level shift in commodity prices). In turn, this raises questions about the process of external adjustment in the face of these large and persistent shocks.

With this in mind, this paper develops an alternative approach to the rest of the literature for identifying episodes of large and persistent shifts in ToT, covering a large set of countries over the period 1960-2015. The approach entails estimating a Markov-switching process with level shifts in ToT. ${ }^{2}$ Then, we document the behavior of key macroeconomic variables over each phase of the terms-of-trade cycle, as well as the process of external adjustment around transition periods (both from low-to-high and from high-to-low ToT, also dubbed booms and busts, respectively). Transition dynamics are also studied within an econometric dynamic panel approach, exploring (i) potential differences between advanced and emerging market economies, (ii) the role of domestic demand and output in the adjustment process, (iii) the buffering effect of the exchange rate and the role of international reserve holdings in smoothing such process, and (iv) how adjustment in the recent episode compares to past episodes.

\footnotetext{
${ }^{2}$ Like the rest of the literature on term-of-trade shocks, the approach taken in this paper does not formally account for the expected persistence of the shocks (in theory, transitory and permanent shocks would be entail different effects). Yet, the focus on large and (ex-post) persistent shocks indicates that these events can be mainly thought of as mostly permanent shifts.
} 
We find that much of the adjustment to positive (negative) terms-of-trade shifts takes place on impact, with current accounts experiencing a contemporaneous strengthening (weakening) of only about $1 / 2$ of the magnitude of the ToT income shock (i.e., trade volumes largely offset the price shock). A full offset is visible within 3-4 years. The external adjustment reflects primarily a response of domestic demand to the gain (loss) of income arising from the change in the ToT. This income effect is exacerbated by the positive response of output to the ToT shock - which is particularly strong in net commodity exporters. In turn, we observe that the income effect is reflected in that most of the adjustment occurs through imports rather than exports (also suggesting a limited expenditure-switching effect).

Adjustment patterns are mostly symmetric for ToT booms and busts, and between advanced economies (AEs) and emerging market and developing economies (EMDEs), although the latter are subject to significantly larger ToT fluctuations.

We also find that exchange rate flexibility plays an important buffering role during booms, with expenditure switching inducing increased spending of the ToT income windfall. Exchage rate flexibility appears to be less relevant in episodes of ToT busts, with rapid external adjustment taking place even under rigid exchange rate regimes, indicating that financing constraints likely prevented a widening of current account deficits in the face of a negative income shock.

Countries tend to rely on reserve accumulation/decumulation as a tool to mitigate the effect of large shifts in ToT, especially when ToT deteriorate. As expected, large holdings of international reserves buffers do not seem to play a role in the context of ToT booms, but are found to play a key role in smoothing the external adjustment process during ToT busts.

Finally, a comparison of the ToT bust recently experienced by commodity exporters - on the back of falling commodity prices - with past episodes indicates that the former event has been, in general, similar to the past. This is especially true for economies with flexible exchange rate regimes. Countries with fixed exchange rate regimes, however, have displayed greater adjustment to their larger shocks (i.e., significant volume offset), possibly indicating their inability or unwillingness to finance large current account deficits.

The rest of the paper is organized as follows. Section II discusses the approach to identify ToT phases and transitions, and documents the behavior of key variables over each phase of the ToT cycle. Section III presents event analysis around ToT transitions and a dynamic panel econometric approach to formally study the process of external adjustment. Section IV extends the analysis to the most recent shift in ToT and puts it in historical perspective. Section V concludes, summarizing the key findings. 


\section{TERMS-OF-TRADE CYCLES}

\section{A. Identification and dating}

In order to identify the different phases of each country's ToT cycle, individual Markov regime-switching models are estimated over the ToT time-series, distinguishing between regimes of low and high ToT, as follows: ${ }^{3}$

$$
\begin{aligned}
& \text { Regime } 1 \text { (High): } \text { Tot }_{t}=\mu_{H}+\varepsilon_{t}, \quad \varepsilon_{t} \sim N\left(0, \sigma^{2}\right) \\
& \text { Regime 2 (Low): } \operatorname{Tot}_{t}=\mu_{L}+\varepsilon_{t}, \quad \varepsilon_{t} \sim N\left(0, \sigma^{2}\right)
\end{aligned}
$$

This identification is used to date the start and end of each phase of a country's ToT cycle, as well as the ToT mean value in each phase $\left(\mu_{H}\right.$ and $\mu_{L}$; with $\left.\mu_{H}>\mu_{L}\right)$. By definition of the Markov-regime switching, statistically large and persistent changes in the average terms of trade are needed for a regime switch to be identified. Figure 1 illustrates this identification for the case of Argentina.

Figure 1. Terms-of-trade cycles in Argentina.

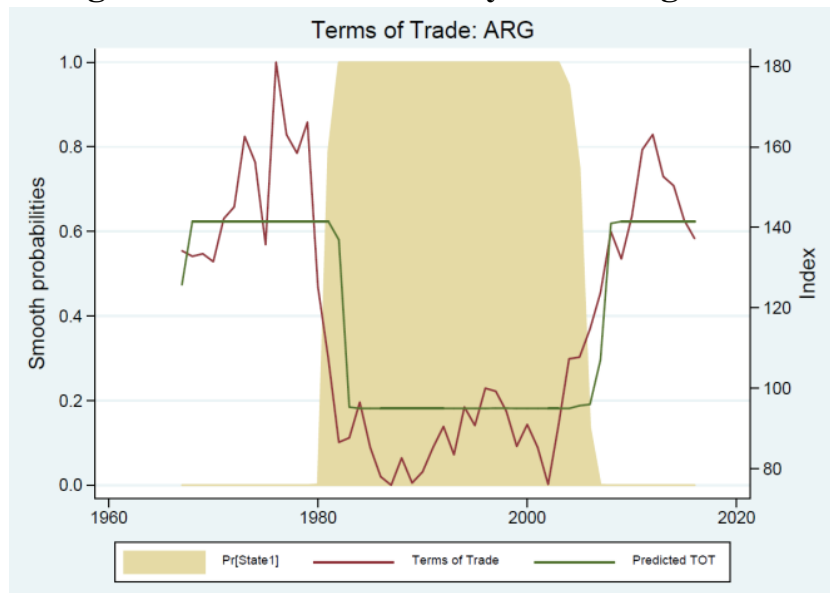

Data cover 150 countries for which ToT series are available for the period 1960-2015. Series come from World Economic Outlook database.

\section{B. Descriptive statistics}

Summary statistics of the identified cycles and their phases are reported in Table 1 . We find 59 episodes of ToT busts and 81 episodes of ToT booms (see the Appendix for a full list). Associated to these regime changes, there are 75 phases of high ToT and 91 phases of low

\footnotetext{
${ }^{3}$ Estimation of Markov-switching models proceeds by predicting the probabilities of unobserved states based on the observed series (in this case, the terms of trade) and updating the likelihood maximization problem at each period, akin to a Kalman filter. For details, see Hamilton (1994).
} 
ToT. ${ }^{4}$ Reflecting their exposure to larger ToT fluctuations, EMDEs dominate the sample of identified ToT cycles, accounting for 63 and 75 percent of high and low phases, respectively. Interestingly, the sample of identified cycles is broadly balanced between net commodity exporters and importers. This reflect that fact that, while most of the price variations are associated to commodity price swings, these can affect both commodity importers and exporters (even if asymmetrically) through import prices in one case and export prices in the other.

Table 1. ToT Phases: Descriptive Statistics.

\begin{tabular}{|c|c|c|c|c|c|c|c|c|c|}
\hline & \multicolumn{2}{|c|}{ Number of Phases } & \multicolumn{2}{|c|}{ Duration $^{1}$} & \multicolumn{2}{|c|}{ Persistence $^{2}$} & \multicolumn{3}{|c|}{ Ratio Low/High Terms of Trade } \\
\hline & Strong & Weak & Strong & Weak & Strong & Weak & Mean & Median & Std Dev \\
\hline Total & 75 & 91 & 19 & 10 & 0.93 & 0.94 & 0.65 & 0.68 & 0.20 \\
\hline Advanced Economies & 28 & 23 & 17 & 12 & 0.94 & 0.93 & 0.83 & 0.86 & 0.10 \\
\hline Emerging and Developing Economies & 47 & 68 & 19 & 10 & 0.92 & 0.95 & 0.60 & 0.64 & 0.19 \\
\hline Flexible Exchange Rate Regime & 22 & 26 & 19 & 11 & 0.93 & 0.95 & 0.65 & 0.69 & 0.19 \\
\hline Net Commodity Exporters & 25 & 49 & 20 & 12 & 0.93 & 0.94 & 0.61 & 0.63 & 0.20 \\
\hline
\end{tabular}

${ }^{1}$ Median duration.

${ }^{2}$ Persistence refers to the probability of remaining in the same phase of the terms-of-trade cycle in each period.

Throughout the sample, terms-of-trade phases are highly persistent, resulting in a high probability of remaining in any given state of nature, as it is apparent in the "Persistence" columns of Table 1. High ToT phases last, on average, 19 years, and low phases about 10-12 years. The long persistence of both phases is visible for both AEs and EMDEs. A higher mean Low/High ToT ratio, along with a smaller standard deviation, for AEs indicates that these countries have more stable ToT in comparison to EMDEs, in part owing to the higher reliance of the latter group on commodity exports.

Table 2 presents summary statistics of some key macroeconomic variables over the phases of the ToT cycle, including means' tests across high and low ToT, controlling for country fixed effects. ${ }^{5}$ On average, ToT are about 50-60 percent higher during the high phase of the cycle. Consistent with more favorable ToT, the real exchange rate is also significantly higher during the high phase of the cycle (about 12 percent), and so are current account balances (about $1 \frac{1}{2}$ percentage points of GDP higher). Real GDP growth, however, does not appear, on average, to be substantially different across regimes. While these pattern hold for both AEs

\footnotetext{
${ }^{4}$ Each country may have more than one of each type of regime switches, depending on the number of identified phases.

${ }^{5}$ The formal means' test of these differences across states, controlling for country-fixed effects, confirms these summary statistics. Specifically, the following specification is estimated: $X_{i}=\alpha+\beta$ ToT $_{-}$Strong $_{i}+\gamma_{i}+\varepsilon_{i}$ where $X$ is either the terms of trade, the real effective exchange rate, the current account balance (in percent of GDP), or real GDP growth. TOT_Strong is a dummy variable that takes the value one for strong terms of trade, and zero otherwise; $\gamma$ denotes a country fixed-effect to demean the value of the country-specific value; $\alpha$ represents the average value of $X$ in the full sample. $\beta$, if positive, implies that when terms of trade are in the strong part of the cycle, the average value of $X$ is higher.
} 
and EMDEs separately, the difference between the high and low phase of the cycle are more pronounced for EMDEs, also reflecting a larger share of commodity exporting countries in the sample.

Table 2. Phases of the ToT cycles. Summary statistics.

\begin{tabular}{|c|c|c|c|c|c|c|c|c|c|c|}
\hline \multirow[b]{2}{*}{ Variable \& Country Group } & \multicolumn{3}{|c|}{ Full sample } & \multicolumn{3}{|c|}{ High ToT } & \multicolumn{3}{|c|}{ Low ToT } & \multirow[b]{2}{*}{$\begin{array}{c}\text { Mean } \\
\text { Test 1/ }\end{array}$} \\
\hline & Obs & Mean & $\begin{array}{l}\text { Std. } \\
\text { Dev. }\end{array}$ & Obs & Mean & $\begin{array}{l}\text { Std. } \\
\text { Dev. }\end{array}$ & Obs & Mean & $\begin{array}{l}\text { Std. } \\
\text { Dev. }\end{array}$ & \\
\hline \multicolumn{11}{|l|}{ All countries } \\
\hline Terms of trade (index) & 2160 & 121.6 & 120.2 & 1036 & 151.9 & 162.9 & 1124 & 93.6 & 41.0 & $60.6^{* * *}$ \\
\hline Real effective exchange rate (index) & 1476 & 113.7 & 78.2 & 701 & 119.4 & 70.9 & 775 & 108.6 & 84.0 & $11.8^{* * *}$ \\
\hline Current account balance (\% of GDP) & 2056 & -2.4 & 13.2 & 973 & -1.6 & 13.6 & 1083 & -3.2 & 12.7 & $1.4^{* * *}$ \\
\hline Real GDP growth (\%) & 1917 & 3.9 & 5.7 & 927 & 4.0 & 5.3 & 990 & 3.8 & 5.9 & 0.3 \\
\hline \multicolumn{11}{|l|}{ Advanced Economies } \\
\hline Terms of trade (index) & 487 & 101.5 & 17.8 & 253 & 109.4 & 18.7 & 234 & 92.9 & 11.9 & $18.3^{* * *}$ \\
\hline Real effective exchange rate (index) & 346 & 101.8 & 19.6 & 160 & 103.6 & 17.3 & 186 & 100.2 & 21.4 & $7.2 * * *$ \\
\hline Current account balance (\% of GDP) & 457 & -0.2 & 5.2 & 229 & 0.0 & 5.3 & 228 & -0.5 & 5.1 & $0.7 *$ \\
\hline Real GDP growth (\%) & 428 & 3.1 & 3.3 & 225 & 3.5 & 3.3 & 203 & 2.8 & 3.2 & $0.8 * *$ \\
\hline \multicolumn{11}{|l|}{ Emerging and Developing Economies } \\
\hline Terms of trade (index) & 1673 & 127.4 & 135.7 & 783 & 165.7 & 185.0 & 890 & 93.7 & 45.7 & $72.9 * * *$ \\
\hline Real effective exchange rate (index) & 1130 & 117.4 & 88.4 & 541 & 124.1 & 79.6 & 589 & 111.2 & 95.5 & $13.2 * *$ \\
\hline Current account balance (\% of GDP) & 1599 & -3.0 & 14.6 & 744 & -2.0 & 15.2 & 855 & -3.9 & 14.0 & $1.6^{* * *}$ \\
\hline Real GDP growth (\%) & 1489 & 4.1 & 6.1 & 702 & 4.2 & 5.8 & 787 & 4.0 & 6.4 & 0.2 \\
\hline \multicolumn{11}{|l|}{ Net Commodity Exporters } \\
\hline Terms of trade (index) & 867 & 109.6 & 50.0 & 435 & 134.5 & 51.6 & 432 & 84.6 & 32.9 & $51.6^{* * *}$ \\
\hline Real effective exchange rate (index) & 611 & 121.1 & 109.7 & 332 & 126.2 & 89.0 & 279 & 115.1 & 130.1 & 9.6 \\
\hline Current account balance (\% of GDP) & 843 & 0.8 & 14.6 & 424 & 1.5 & 15.0 & 419 & 0.2 & 14.1 & 1.2 \\
\hline Real GDP growth $(\%)$ & 814 & 4.2 & 6.2 & 418 & 4.3 & 5.5 & 396 & 4.0 & 6.9 & 0.2 \\
\hline \multicolumn{11}{|l|}{ Net Commodity Importers } \\
\hline Terms of trade (index) & 1293 & 129.6 & 149.4 & 601 & 164.6 & 208.5 & 692 & 99.2 & 44.4 & $66.7^{* * *}$ \\
\hline Real effective exchange rate (index) & 865 & 108.5 & 43.4 & 369 & 113.3 & 48.7 & 496 & 104.9 & 38.6 & $13.5^{* * *}$ \\
\hline Current account balance (\% of GDP) & 1213 & -4.7 & 11.5 & 549 & -3.9 & 11.9 & 664 & -5.3 & 11.2 & $1.6^{* * *}$ \\
\hline Real GDP growth (\%) & 1103 & 3.7 & 5.2 & 509 & 3.8 & 5.2 & 594 & 3.6 & 5.2 & 0.4 \\
\hline
\end{tabular}

\section{REGIMES SWITCHES}

\section{A. Stylized Facts}

Our main interest is in the adjustment process that takes place in the transition between ToT phases. Thus, we first conduct event analysis for transitions, looking at 10-year windows centered around the identified year of the regime switch. All the events are stacked, centered in $t=0$, and ToT booms and ToT busts are studied separately. Series are demeaned (by event) to filter out cross-country level differences. Figure 2 below illustrates the dynamics of key variables around these transitions.

As expected, ToT shifts are significantly more pronounced in EMDEs than in AEs. The median ToT shift is about 40 percentage points in EMDEs, in both directions (booms and bust), compared to about only 20 percentage points for AEs. Moreover, the variance around these means is significantly larger for the former group. These reflect a greater reliance of 
EMDEs on commodities' exports, and a wider dispersion in the degree of commodity reliance in this group relative to AEs.

Figure 2. Terms-of-trade during transitions. AEs and EMDEs. (index, demeaned)
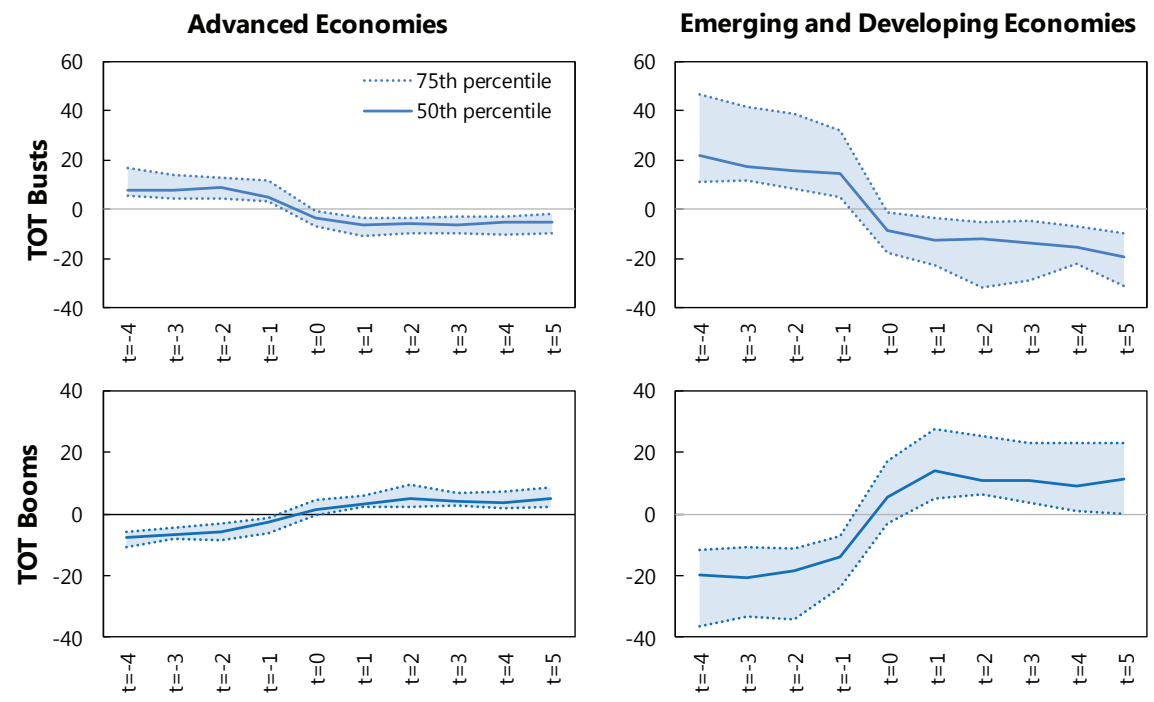

Sources: IMF, World Economic Outlook database; and IMF staff calculations.

As expected, strengthening (weakening) terms-of-trade resulted in stronger (weaker) currencies in both income groups (Figure 3), although more pronounced in EMDEs, reflecting larger ToT variations. Interestingly, though, the response of real exchange rates appears to occur with a lag, relative to the ToT shock, possibly indicating the presence of policies to mitigate exchange rate movements, as discussed in more detail below.

Figure 3. Real effective exchange rate during ToT transitions. (index, demeaned)
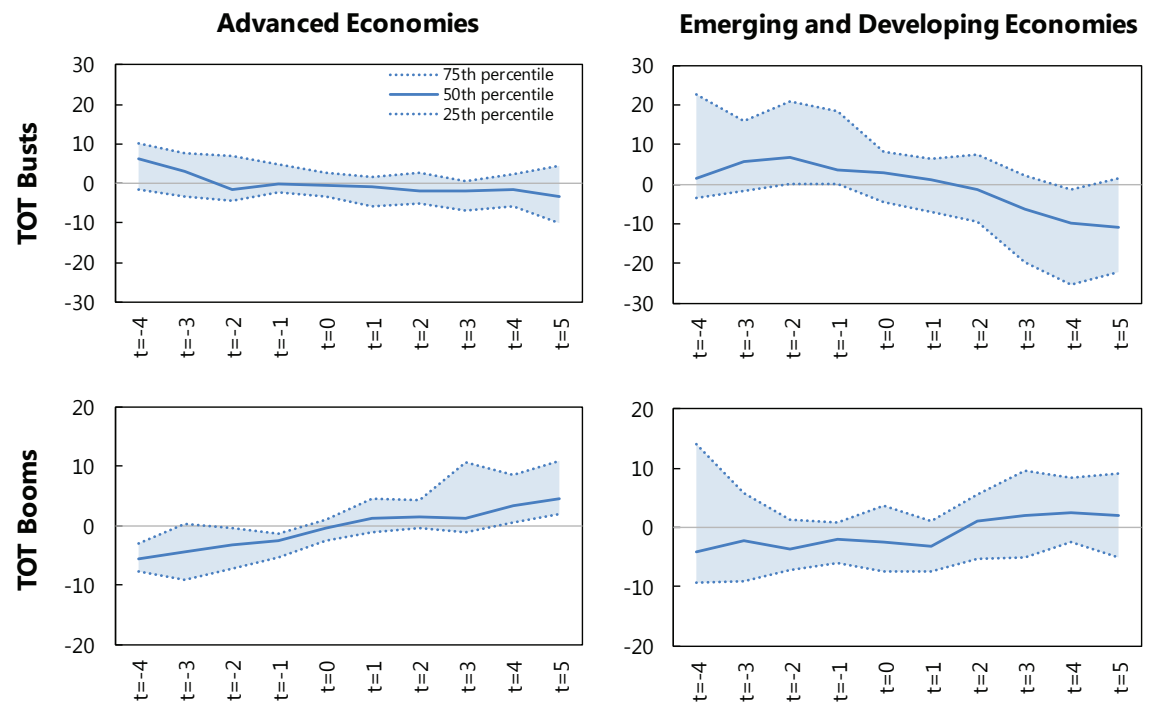

Sources: IMF, Information Notice System database; and IMF staff calculations. 
The effect of ToT shifts is visible, contemporaneously, in current account balances of both income groups (Figure 4). External accounts of EMDEs appear more sensitive to ToT shocks - reflecting not only larger shocks, but also a more limited ability to adjust to the shock. Within 3-4 years, however, the effect on current accounts appears to have dissipated - despite the fact that ToT remain under the new regime - suggesting that a full adjustment to the shock takes place within this time horizon.

Figure 4. Current account balance during ToT transitions. (percent of GDP, demeaned)

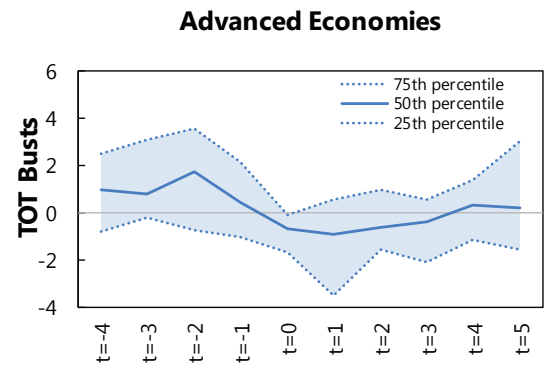

Emerging and Developing Economies
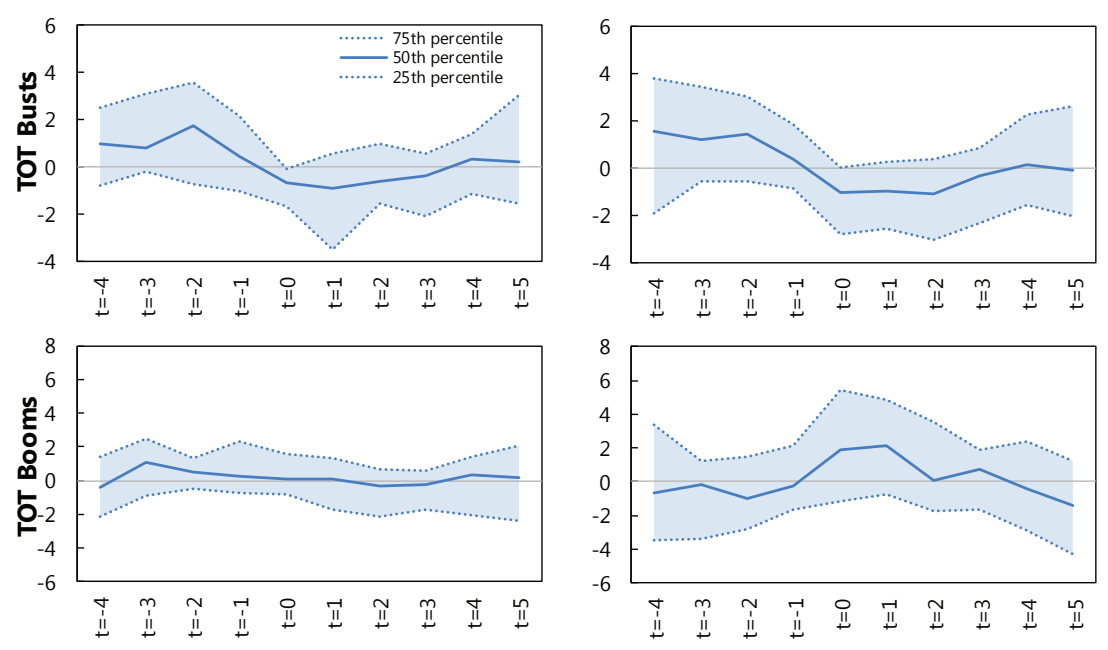

Sources: IMF, World Economic Outlook database; and IMF staff calculations.

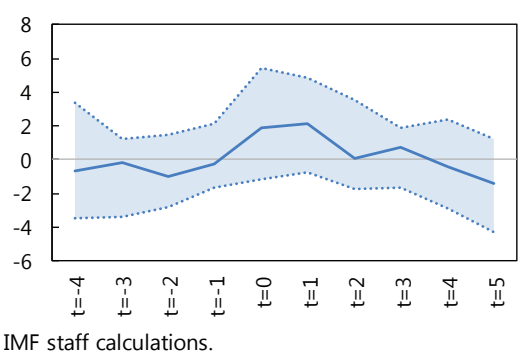

Finally, a breakdown between net commodity exporters and importers, not shown here, indicates that the former group tends to face much larger ToT variations (in both booms and busts) in comparison to the latter group. ${ }^{6}$ Consequently, in general, their currencies and current account balances tend to be subject to larger fluctuations.

\section{B. Econometric Approach}

To formally study the pattern of adjustment and the role of policies, we undertake a multivariate dynamic panel econometric exercise. Following the stylized facts above, as booms and busts are analyzed separately, we estimate the following specification for the stacked set of identified booms and busts, separately:

$$
y_{j, t}=\alpha+\gamma y_{j, t-1}+\sum_{l=0}^{L} \beta_{t-l} \Delta T o T_{t-l}+\delta X_{t}+\varepsilon_{t}
$$

where $y_{j, t}$ denotes the endogenous macroeconomic variable of interest study for country $j$ at episode-year $t$. Specifically, equation (2) is estimated, one at the time, for the current account

\footnotetext{
${ }^{6}$ See Appendix Figures A.1-A.4.
} 
balance, the real effective exchange rate, net trade volumes, real domestic demand, real output, and the stock of international reserves.

The regressor of interest is the measure of the exogenous change in the terms of trade, $\Delta T o T$. Following Adler and Magud (2015), we rely on a measure of ToT shock that takes into account the degree of trade openness and captures the direct income shock associate to the variation in trade prices. Specifically, $\Delta T O T$ is given by:

$$
\Delta T o T_{j, t}=\left[\frac{P_{j, t}^{X}}{P_{j, t-1}^{X}} \frac{1}{\left(1+\pi_{U S, t}\right)}-1\right] \times X_{j, t-1}-\left[\frac{P_{j, t}^{M}}{P_{j, t-1}^{M}} \frac{1}{\left(1+\pi_{U S, t}\right)}-1\right] \times M_{j, t-1}
$$

where $P^{X}\left(P^{M}\right)$ denotes export (import) price deflator expressed in U.S. dollars; $X(M)$ is the share of exports (imports) to GDP, and $\pi$ is the U.S. inflation rate. ${ }^{7}$ Since this measure reflects the income shock associated to the change in the ToT, expressed in percentage points of GDP, the regression coefficients should be interpreted as the response of the left-hand-side variable to an income shock equal to 1 percent of GDP. Lags of $\Delta T o T$ are included to explore dynamic effects (beyond those captured by the autoregressive coefficient, $\gamma$ ).

Controls for other key common external factors, $X_{t}$, are also included. These entail controlling for global financial conditions - encompassed in the U.S. real interest rate and a measure of global financial markets volatility, computed as the annual standard deviation of daily observations of the Standard and Poor's 500 index - and for external demand, proxied by the growth rate of world's real GDP. The sources of these variables are, respectively, Saint Louis Fed (FRED), Bloomberg, and the IMF's World Economic Outlook.

Based on annual frequency data, the time span of the panel goes from $t-4$ to $t+5$ (i.e., 10 years for each transition event). The estimation is based on the Arellano-Bond's generalized method of moments (GMM), given the panel's short time-span. The specification is estimated for the full sample, as well as for the subsamples of AEs and EMDEs separately.

Impulse-response functions are computed as the non-linear combinations of the relevant estimated coefficients $(\gamma$, and the $\beta s$ ) with the corresponding confidence intervals.

\section{Results}

\section{Average effects}

Table 3 and Figure 5 summarize key results for the baseline specification. We find that current accounts react significantly to ToT (i.e., price) shocks, indicating that there is not a full volume adjustment on impact. A one percent of GDP positive ToT shock leads, on average, to a $1 / 2$ percent of GDP improvement of the current account on impact, meaning that

\footnotetext{
${ }^{7}$ Deflating export and import price deflators with U.S. inflation rate is key when looking at terms-of-trade income shocks prior to 1980 , as otherwise price variations simply reflecting high U.S. inflation would distort the analysis.
} 
only $1 / 2$ of the price shock is offset by a variation of trade volumes. This pattern of adjustment is highly symmetrical between positive and negative shocks, although with a somewhat faster adjustment in the case of negative shocks. There is also a striking degree of symmetry between the responses in AEs and EMDEs (as shown in Figure 5 right-most column). The process of adjustment over time is relatively fast, fully taking place within a 3-4 year horizon.

Table 3. Current Accounts and REER response to ToT shifts

\begin{tabular}{|c|c|c|c|c|c|c|c|c|c|c|c|c|}
\hline \multirow{3}{*}{$\begin{array}{l}\text { Dependent variable: } \\
\text { Country sample: } \\
\text { Variables }\end{array}$} & \multicolumn{6}{|c|}{ ToT Booms } & \multicolumn{6}{|c|}{ ToT Busts } \\
\hline & \multicolumn{3}{|c|}{ Current Account } & \multicolumn{3}{|c|}{ Real Exchange Rate } & \multicolumn{3}{|c|}{ Current Account } & \multicolumn{3}{|c|}{ Real Exchange Rate } \\
\hline & $\begin{array}{l}\text { All } \\
(1) \\
\end{array}$ & $\begin{array}{r}\text { AEs } \\
(2) \\
\end{array}$ & $\begin{array}{c}\text { EMDEs } \\
(3)\end{array}$ & $\begin{array}{l}\text { All } \\
(4) \\
\end{array}$ & $\begin{array}{r}\text { AEs } \\
(5) \\
\end{array}$ & $\begin{array}{c}\text { EMDEs } \\
(6) \\
\end{array}$ & $\begin{array}{l}\text { All } \\
(7) \\
\end{array}$ & $\begin{array}{r}\text { AEs } \\
(8) \\
\end{array}$ & $\begin{array}{c}\text { EMDES } \\
(9)\end{array}$ & $\begin{array}{l}\text { All } \\
(10) \\
\end{array}$ & $\begin{array}{l}\text { AEs } \\
(11) \\
\end{array}$ & $\begin{array}{c}\text { EMDEs } \\
(12) \\
\end{array}$ \\
\hline L.Y & $\begin{array}{r}0.59 * * * \\
(0.02)\end{array}$ & $\begin{array}{r}0.71^{* * *} \\
(0.04)\end{array}$ & $\begin{array}{r}0.62^{* * *} \\
(0.02)\end{array}$ & $\begin{array}{r}0.58^{* * *} \\
(0.02)\end{array}$ & $\begin{array}{r}0.79^{* * *} \\
(0.04)\end{array}$ & $\begin{array}{r}0.58^{* * *} \\
(0.02)\end{array}$ & $\begin{array}{r}0.68^{* * *} \\
(0.02)\end{array}$ & $\begin{array}{r}0.61^{* * *} \\
(0.06)\end{array}$ & $\begin{array}{r}0.72^{* * *} \\
(0.02)\end{array}$ & $\begin{array}{r}0.50^{* * *} \\
(0.02)\end{array}$ & $\begin{array}{r}0.65^{* * *} \\
(0.05)\end{array}$ & $\begin{array}{r}0.56^{* * *} \\
(0.03)\end{array}$ \\
\hline TOT shock & $\begin{array}{r}0.45^{* * *} \\
(0.03)\end{array}$ & $\begin{array}{r}0.55^{* * *} \\
(0.08)\end{array}$ & $\begin{array}{r}0.44 * * * \\
(0.03)\end{array}$ & $\begin{array}{r}-0.17 \\
(0.17)\end{array}$ & $\begin{array}{r}0.81^{* * *} \\
(0.15)\end{array}$ & $\begin{array}{c}-0.23 \\
(0.20)\end{array}$ & $\begin{array}{r}0.51^{* * *} \\
(0.05)\end{array}$ & $\begin{array}{r}0.61^{* * *} \\
(0.10)\end{array}$ & $\begin{array}{r}0.50^{* * * *} \\
(0.06)\end{array}$ & $\begin{array}{r}0.28^{* * *} \\
(0.09)\end{array}$ & $\begin{array}{r}0.35^{* *} \\
(0.17)\end{array}$ & $\begin{array}{r}0.26 * * \\
(0.11)\end{array}$ \\
\hline L.TOT shock & $\begin{array}{r}0.14^{* * *} \\
(0.03)\end{array}$ & & $\begin{array}{r}0.12^{* * *} \\
(0.03)\end{array}$ & & $\begin{array}{r}0.52^{* * *} \\
(0.13)\end{array}$ & & & & & & $\begin{array}{r}0.42 * * \\
(0.17)\end{array}$ & \\
\hline L2.TOT shock & $\begin{array}{r}0.12 * * * \\
(0.03)\end{array}$ & & $\begin{array}{r}0.10^{* * *} \\
(0.03)\end{array}$ & & & & & & & & & \\
\hline Constant & $\begin{array}{r}-0.68 * * * \\
(0.18) \\
\end{array}$ & $\begin{array}{r}-0.56^{* * *} \\
(0.18) \\
\end{array}$ & $\begin{array}{r}-0.59 * * \\
(0.24)\end{array}$ & $\begin{array}{r}45.33^{* * *} \\
(2.20) \\
\end{array}$ & $\begin{array}{r}21.35^{* * * *} \\
(3.78) \\
\end{array}$ & $\begin{array}{r}45.88^{* * *} \\
(2.66) \\
\end{array}$ & $\begin{array}{r}-0.37^{* *} \\
(0.18) \\
\end{array}$ & $\begin{array}{r}-0.57^{* *} \\
(0.25) \\
\end{array}$ & $\begin{array}{r}-0.27 \\
(0.24) \\
\end{array}$ & $\begin{array}{r}48.90 * * * \\
(2.42) \\
\end{array}$ & $\begin{array}{r}35.19 * * * \\
(5.10) \\
\end{array}$ & $\begin{array}{r}42.40 * * * \\
(2.76) \\
\end{array}$ \\
\hline Number of observations & 710 & 193 & 539 & 803 & 192 & 608 & 584 & 192 & 392 & 574 & 181 & 388 \\
\hline Number of countries & 82 & 21 & 62 & 84 & 20 & 63 & 62 & 21 & 41 & 61 & 20 & 41 \\
\hline Adjusted R2 & 0.15 & 0.00 & 0.35 & 0.00 & 0.13 & 0.00 & 0.84 & 0.08 & 0.72 & 0.00 & 0.03 & 0.00 \\
\hline Sargan P value & 0.000 & 0.000 & 0.000 & 0.000 & 0.000 & 0.000 & 0.000 & 0.000 & 0.000 & 0.000 & 0.000 & 0.000 \\
\hline Sargan Test & 788.9 & 214.4 & 603.6 & 1277 & 301.8 & 966.3 & 477.2 & 188.5 & 324.3 & 903.7 & 232.5 & 629.6 \\
\hline
\end{tabular}

Figure 5. Impulse-Response Functions

(response to a lpp of GDP ToT shock).
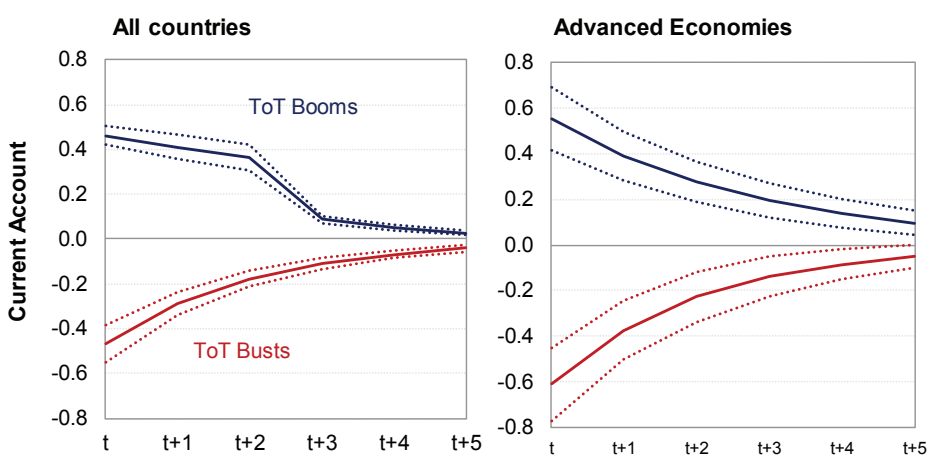

EMDEs
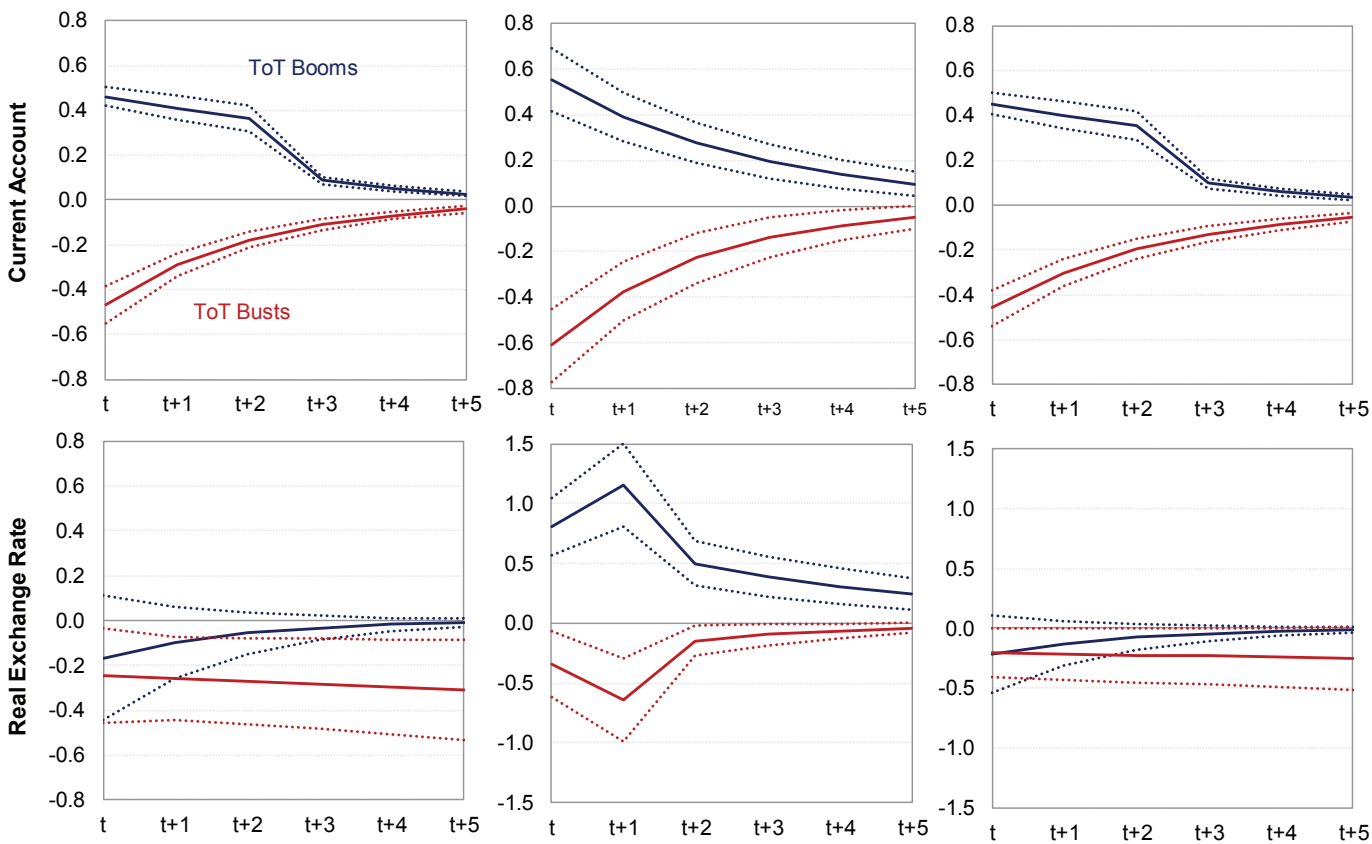

Sources: Authors' estimates.

Impulse responses to a terms-of-trade income shock of 1 percent of GDP, and 90 percent confidence bands, are reported. See Adler and Magud (2015) for a detailed discussion on how to measure income shocks associated to terms-of-trade variations. 
Interestingly, real exchange rates appear to respond more strongly to ToT shocks in AEsspecially for ToT booms - than in EMDEs, indicating that they play a greater buffering role in the former group. Indeed, the limited response of the real exchange rate in EMDEs partly reflects a greater proportion of countries with fixed exchange rate regimes.

\section{Exchange rate regime and the role of international reserves}

We explore also the role of policy variables and buffers, such as the exchange rate regime and the level of international reserves, by splitting the sample according to these country characteristics. Exchange rate regimes are based on Ilsetzki et al (2016) and evaluated at the beginning of the episode. ${ }^{8,9}$ For policy buffers, we use a dummy variable that takes value one for country/events with a ratio of international reserves-to-GDP higher than the sample median, and zero otherwise, also evaluated at the beginning of each episode.

Table 4 and Figure 6 present these results. Consistent with its function as shock absorber, economies with exchange rate flexibility display a significantly more muted current account impact in response to positive ToT shocks, indicating that exchange rate flexibility facilitates the offsetting adjustment in trade volumes. There is no evidence, however, of a statically significant difference in current account responses to a negative ToT shock. This arguably indicates that countries with fixed exchange rate regimes have been historically unable to finance large current account deficits, and thus their trade volumes had to adjust even in absence of exchange rate effects. The evidence on reserve holding is consistent with this interpretation.

\footnotetext{
${ }^{8}$ We use the coarse classification, labeling as fixed exchange rate regimes those classified, in the period before the regime switch, as either 1 or 2, and as flexible regimes those with classifications 3, 4, or 5. Exchange rate regimes are highly persistence.

${ }^{9}$ Episodes where the exchange rate regime changed following a ToT shock are excluded from the analysis.
} 
Table 4. Current Accounts and REER response to ToT shifts

\begin{tabular}{|c|c|c|c|c|c|c|c|c|}
\hline \multirow[b]{2}{*}{ Dependent variable: } & \multicolumn{4}{|c|}{ ToT Booms } & \multicolumn{4}{|c|}{ ToT Busts } \\
\hline & \multicolumn{4}{|c|}{ Current Account } & \multicolumn{4}{|c|}{ Current Account } \\
\hline $\begin{array}{l}\text { Country sample: } \\
\text { Variables }\end{array}$ & $\begin{array}{c}\text { Flex ER } \\
\text { Regime } \\
(1)\end{array}$ & $\begin{array}{c}\text { Fixed ER } \\
\text { Regime } \\
(2)\end{array}$ & $\begin{array}{c}\begin{array}{c}\text { High } \\
\text { Reserves }\end{array} \\
(3)\end{array}$ & $\begin{array}{c}\begin{array}{c}\text { Low } \\
\text { Reserves }\end{array} \\
(4)\end{array}$ & $\begin{array}{c}\text { Flex ER } \\
\text { Regime } \\
(5)\end{array}$ & $\begin{array}{c}\text { Fixed ER } \\
\text { Regime } \\
(6)\end{array}$ & $\begin{array}{c}\begin{array}{c}\text { High } \\
\text { Reserves }\end{array} \\
(7)\end{array}$ & $\begin{array}{c}\begin{array}{c}\text { Low } \\
\text { Reserves }\end{array} \\
(8)\end{array}$ \\
\hline L.Y & $\begin{array}{r}0.62 * * * \\
(0.05)\end{array}$ & $\begin{array}{r}0.53 * * * \\
(0.03)\end{array}$ & $\begin{array}{r}0.58 * * * \\
(0.03)\end{array}$ & $\begin{array}{r}0.80 * * * \\
(0.03)\end{array}$ & $\begin{array}{r}0.65^{* * * *} \\
(0.06)\end{array}$ & $\begin{array}{r}0.30 * * * \\
(0.05)\end{array}$ & $\begin{array}{r}0.77 * * * \\
(0.03)\end{array}$ & $\begin{array}{r}0.12^{* *} \\
(0.06)\end{array}$ \\
\hline TOT shock & $\begin{array}{r}0.28 * * * \\
(0.06)\end{array}$ & $\begin{array}{r}0.39 * * * \\
(0.03)\end{array}$ & $\begin{array}{r}0.51 * * * \\
(0.03)\end{array}$ & $\begin{array}{r}0.40 * * * \\
(0.05)\end{array}$ & $\begin{array}{r}0.33^{* * *} \\
(0.09)\end{array}$ & $\begin{array}{r}0.27 * * * \\
(0.04)\end{array}$ & $\begin{array}{r}0.69 * * * \\
(0.08)\end{array}$ & $\begin{array}{r}0.18^{* * *} \\
(0.04)\end{array}$ \\
\hline L.TOT shock & $\begin{array}{r}-0.11^{* *} \\
(0.05)\end{array}$ & $\begin{array}{r}0.15^{* * *} \\
(0.03)\end{array}$ & $\begin{array}{r}0.11 * * * \\
(0.03)\end{array}$ & & $\begin{array}{r}0.11 \\
(0.08)\end{array}$ & $\begin{array}{r}0.20 * * * \\
(0.04)\end{array}$ & & \\
\hline L2.TOT shock & & $\begin{array}{r}0.13^{* * *} \\
(0.03)\end{array}$ & & & & & & \\
\hline Constant & $\begin{array}{r}-0.36 \\
(0.25) \\
\end{array}$ & $\begin{array}{r}-1.21^{* * *} \\
(0.23) \\
\end{array}$ & $\begin{array}{r}-0.49 * * \\
(0.22)\end{array}$ & $\begin{array}{r}-0.39 \\
(0.33) \\
\end{array}$ & $\begin{array}{r}-0.36 \\
(0.23) \\
\end{array}$ & $\begin{array}{r}-2.01^{* * *} \\
(0.210) \\
\end{array}$ & $\begin{array}{r}0.03 \\
(0.33) \\
\end{array}$ & $\begin{array}{r}-2.19 * * * \\
(0.20)\end{array}$ \\
\hline Number of observations & 205 & 409 & 403 & 355 & 166 & 330 & 267 & 276 \\
\hline Number of countries & 21 & 48 & 41 & 38 & 19 & 35 & 28 & 29 \\
\hline Adjusted R2 & 0.40 & 0.26 & 0.04 & 0.14 & 0.54 & 0.63 & 0.87 & 0.04 \\
\hline Sargan $P$ value & 0.000 & 0.000 & 0.000 & 0.000 & 0.000 & 0.000 & 0.000 & 0.000 \\
\hline Sargan Test & 189.5 & 398.4 & 408.4 & 342.8 & 178.9 & 350.6 & 228.7 & 273.2 \\
\hline
\end{tabular}

Figure 6. Current account responses, by exchange rate regime and level of international reserves.
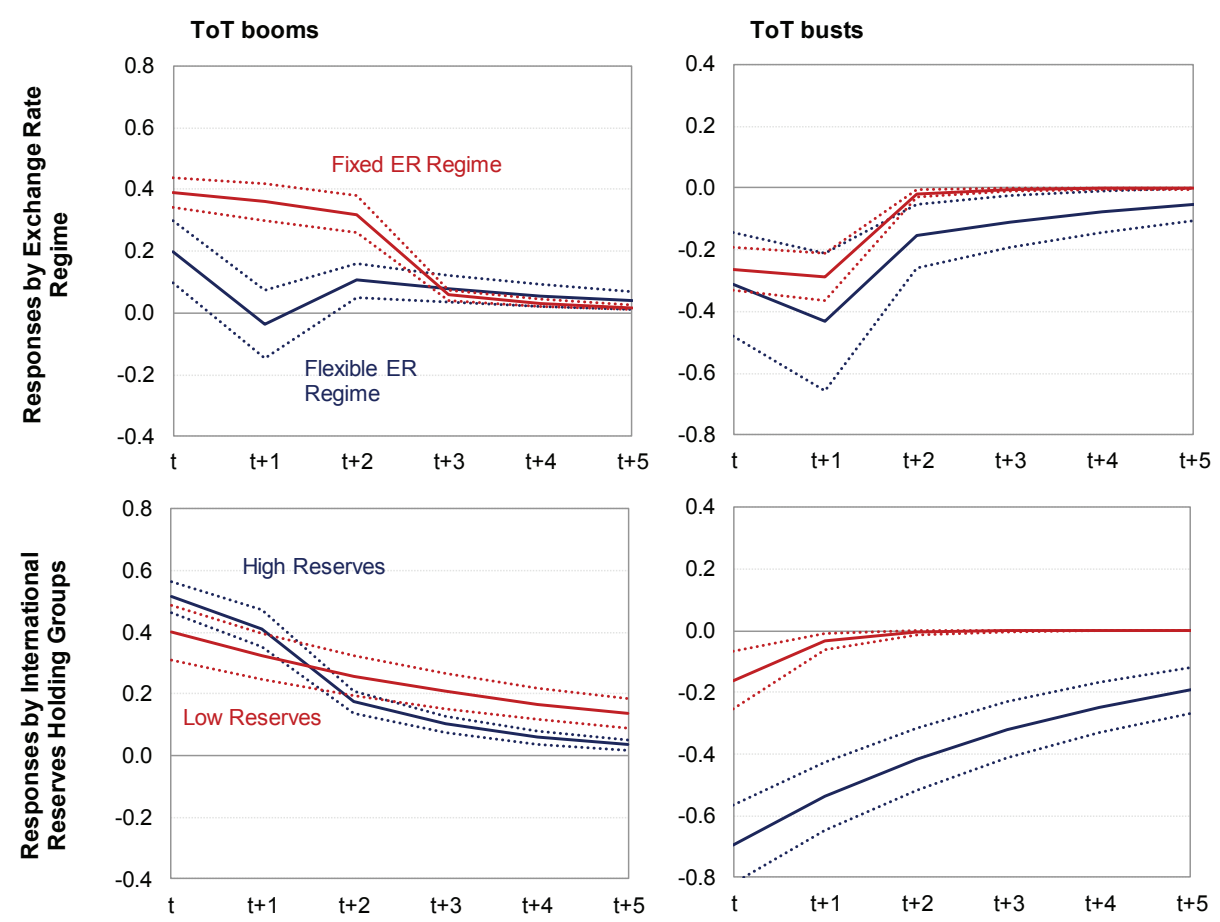

Sources: authors' estimates.

Impulse responses to a 1 percent of GDP terms-of-trade shock, with 90 percent confirdence bands, are reported.

The initial level of reserves holdings matters, especially in the case of negative shocks. Faced with falling ToT shocks, countries with higher levels of international reserves have been able 
to significantly smooth (i.e., delay) the adjustment process, relative to economies with low reserves - for which the limited amount of reserves operated as a constraint on their ability to finance large current account deficits. In the case of positive shocks, with no constraint on reserve accumulation, there is no statistically significant difference between the two groups - as expected.

\section{Robustness}

Several robustness checks are undertaken. First, countries that — due to being large relative to the world economy or having a large export share in commodity world markets - may affect their own ToT are excluded from the sample, as the assumption of exogeneity of ToT may not hold for these cases. Second, episodes with small ToT shifts- for which other factors may dominate the current account dynamics - are excluded. This is done by focusing only on ToT drops or increases of more than 20 percent (i.e., $\left.\left|\mu_{H}-\mu_{L}\right|>.2\right) \cdot{ }^{10}$ Third, additional controls that capture global financial conditions - which may affect the countries' saving and investment dynamics, and thus their current accounts - are included. Fourth, we control also for possible contemporaneous shifts in the demand from trading partners, which may be correlated with ToT variations and have a significant bearing on the dynamics of the current account. These additional exercises, presented in appendix Table A.2, show that, in general, the baseline results hold.

\section{EXTENSIONS}

\section{Domestic adjustment}

To gain further insights on how economies have historically adjusted to large ToT shifts, we explore the behavior of the domestic counterparts of the observed external adjustment process, by decomposing variations in the trade balance into the domestic demand and output (supply) changes.

Consider the definition of the trade balance, $T B=X-M=P^{X} Q^{X}-P^{M} Q^{M}$, where $X(M)$ denotes the value of exports (imports); $P^{X}\left(P^{M}\right)$ denotes the export (import) price deflator; and $Q^{X}\left(Q^{M}\right)$ denotes export (import) volumes. Differentiating and expressing in percent of GDP yields:

$$
\frac{d T B}{Y}=\left[\frac{d P^{X}}{P^{X}} \frac{X}{Y}-\frac{d P^{M}}{P^{M}} \frac{M}{Y}\right]+\left[\frac{d Q^{X}}{Q^{X}} \frac{X}{Y}-\frac{d Q^{M}}{Q^{M}} \frac{M}{Y}\right]=\frac{d T B^{P}}{Y}+\frac{d T B^{R}}{Y}
$$

\footnotetext{
${ }^{10}$ This restriction entails dropping a relatively large number of episodes of AEs, as the relatively low degree of dependence on commodities causes their ToT to fluctuate significantly less than those of EMDEs.
} 
The first term on the right hand side captures the 'income windfall' arising from the change in the ToT (i.e., price changes only), ${ }^{11}$ while the second term shows the variation in trade volumes. Our interest is in dissecting this second term.

From national accounts' identities, the trade balance (expressed in real terms) can be written in terms of its domestic counterparts, meaning domestic demand $\left(D D^{R}\right)$, and output $\left(Y^{R}\right)$, as $T B^{R}=Y^{R}-D D^{R}$, from which follows:

$$
\frac{d T B^{R}}{Y^{R}}=\frac{d Y^{R}}{Y^{R}}-\frac{d D D^{R}}{D D^{R}} \frac{D D^{R}}{Y^{R}}
$$

Thus, variations in net trade volumes can be decomposed into the corresponding change in real output (i.e., real GDP) and the change in real domestic demand (given the share of domestic demand to output).

Figure 7 presents the behavior of each of these terms (ToT windfall income, net trade volumes, ${ }^{12}$ output, and domestic demand, respectively) during the ToT transitions. A prominent feature is the role of domestic demand as the main driver of external adjustment, while changes in output are quite limited, both in episodes of ToT booms and busts. Moreover, while limited, output tends to respond positively to ToT shocks (e.g., expanding with strengthening ToT). As a result, domestic demand responds more than one-to-one to the ToT shock, in order to stabilize the current account.

\footnotetext{
${ }^{11}$ See Adler and Magud (2015) for estimates of terms-of-trade income windfalls during historical episodes of large ToT shocks.

${ }^{12}$ Variation in the trade balance follow closely the variations in the current accounts, as the income balance tends to be small and quite stable.
} 
Figure 7. Anatomy of external adjustment.

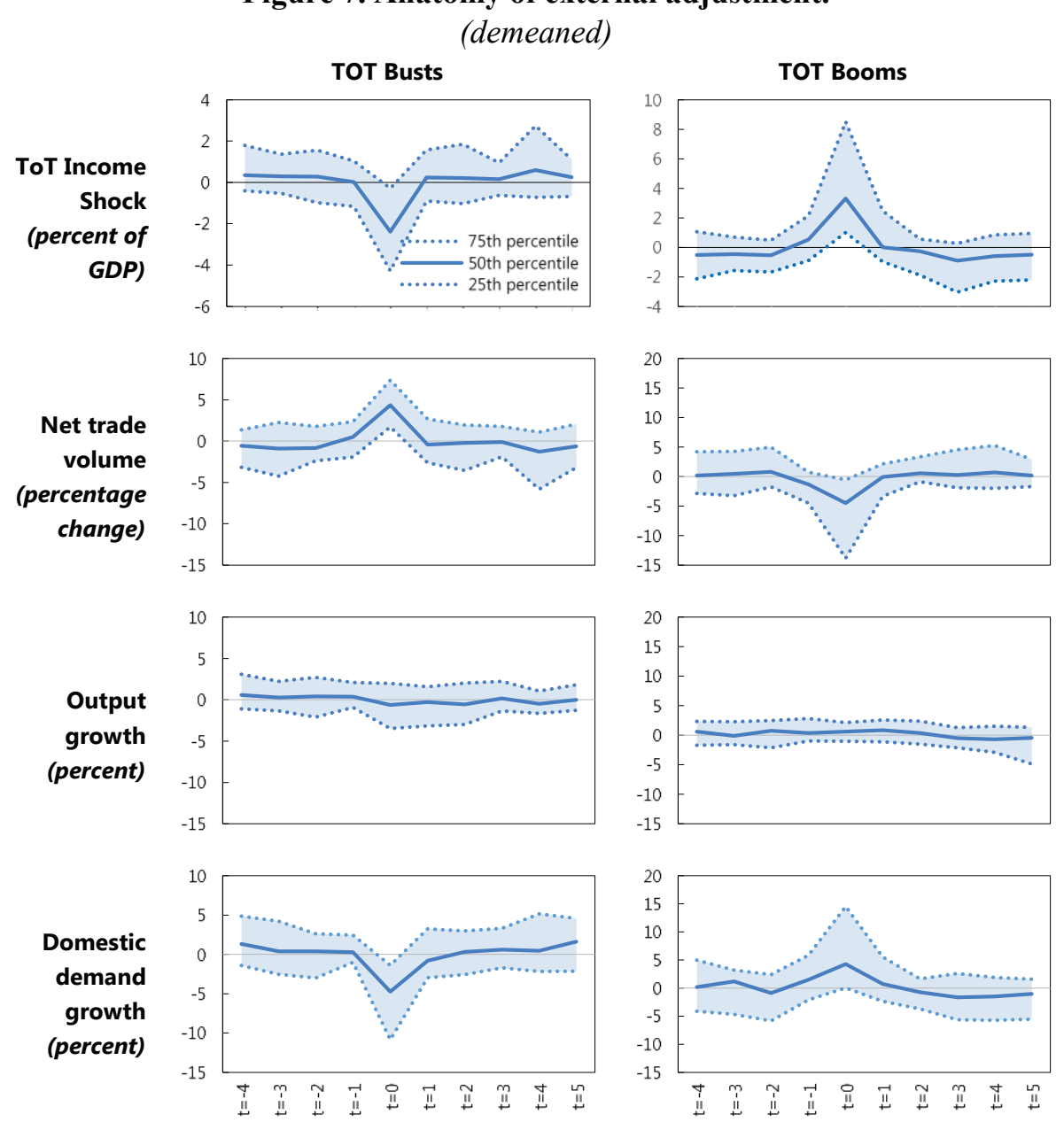

Sources: IMF International Financial Statistics, World Economic Outlook, and authors' calculations.

Figures 8 and 9 replicate the above exercise for ToT busts and booms, respectively, focusing on the differences between net commodity exporters and importers. While in general we find a limited output response for both groups - with domestic demand mirroring the changes in trade volumes - there is evidence of some asymmetric effects. Net commodity exporters seem to face larger output and domestic demand decelerations (accelerations) than importers, when facing ToT busts (booms). This pattern partly reflects larger ToT shocks in the former group, but also reflects the fact that ToT variations are mostly driven by changes in commodity prices, leading to different responses from export and import volumes (see also Figure A.5). For net commodity exporters, variations in commodity prices entail a change in incentives to produce commodities of first order importance, thus affecting output, while for 
commodity importers, these shocks entail mostly income gains and losses with more ambiguous effects on output. ${ }^{13}$

Figure 8. External adjustment during ToT busts:

\section{Commodity exporters vs. importers} (demeaned)
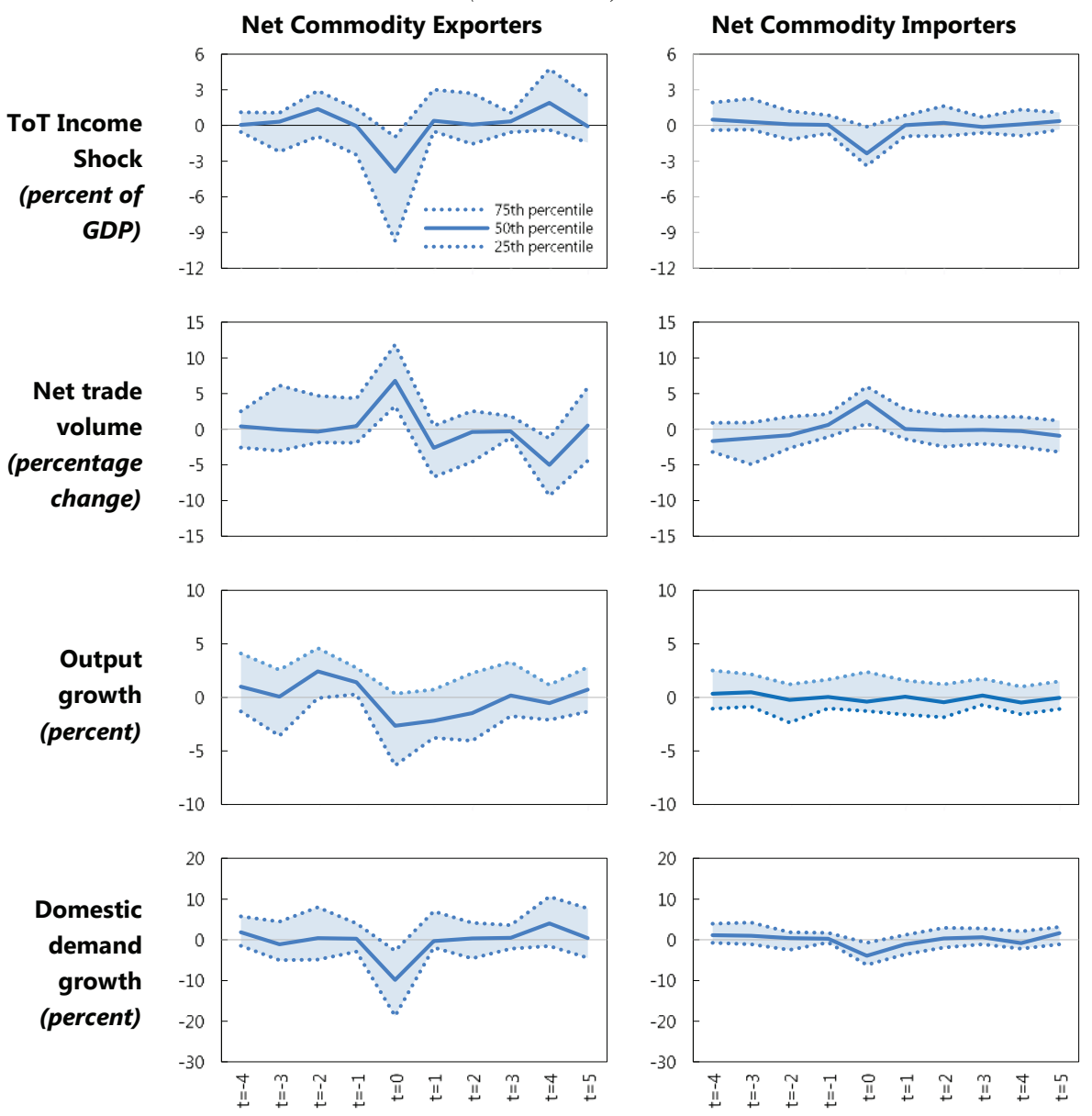

Sources: IMF International Financial Statistics, World Economic Outlook, and authors' calculations.

As shown above for the full sample, external adjustment is driven primarily by domestic demand in both AEs and EMDEs commodity exporters. These effects are stronger in the latter group, however (see Appendix Figure A.4). A further disaggregation of the trade balance into exports/imports volumes and prices, indicates that ToT busts are driven primarily by falling export prices, as opposed to raising imports prices. This reflects the fact that, for commodity importers the share of commodity imports to total imports is relatively low. Thus, commodity price increases, even if large, only have limited impact on their ToT. Consistent with the findings about the role of domestic demand, import volumes play a

\footnotetext{
${ }^{13}$ Varying commodity prices may also affect the cost of certain production inputs for commodity importing countries, but this is likely a second order effect.
} 
dominant role in the adjustment process, contracting significantly in response to the negative ToT shock, while exports volumes react only modestly (see Appendix Figure A.5).

Figure 9. Anatomy of external adjustment during booms:

Commodity exporters vs. importers (demeaned)
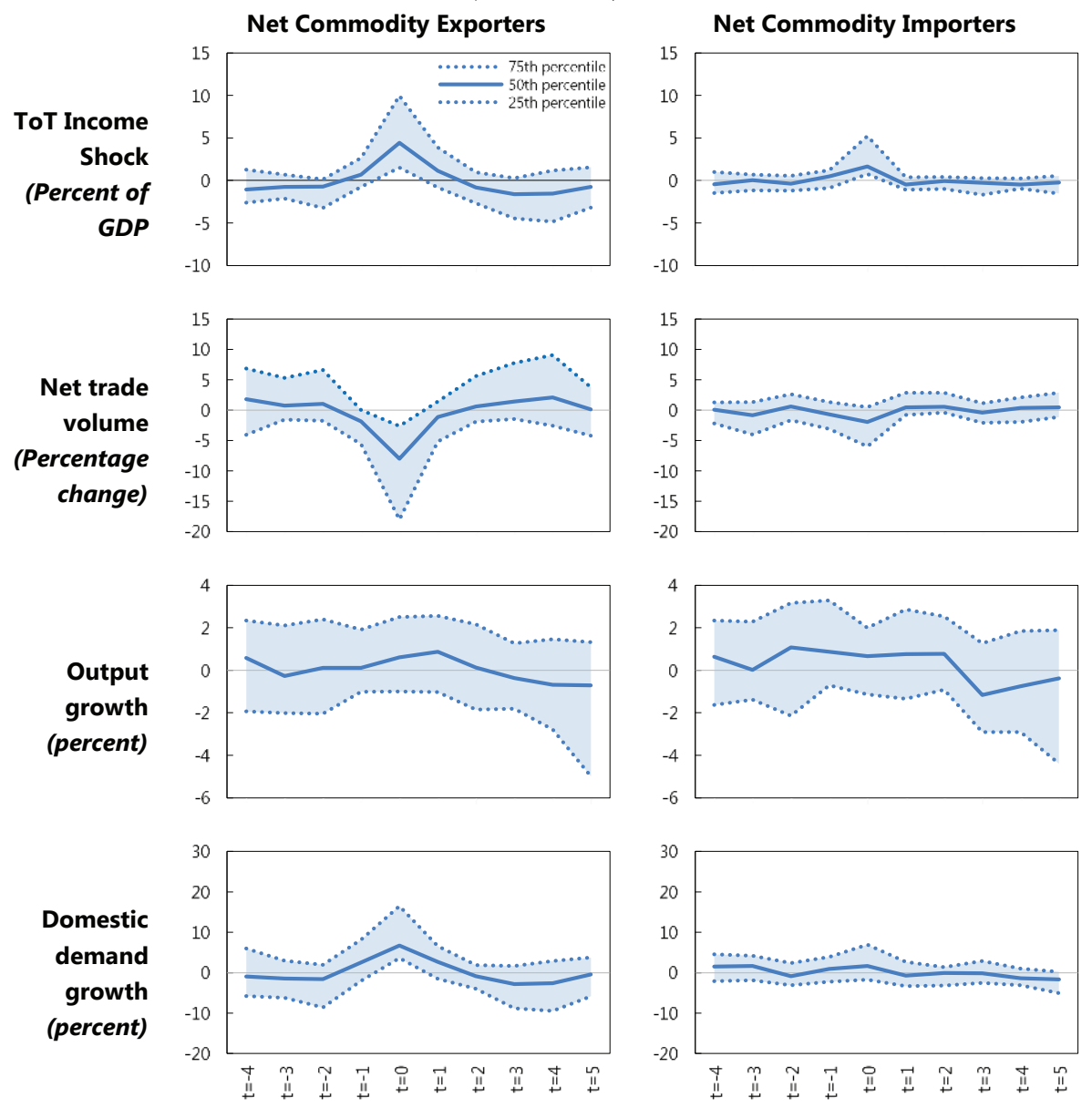

Sources: IMF International Financial Statistics, World Economic Outlook, and authors' calculations.

\section{The recent episode in historical perspective}

Finally, we explore the ongoing adjustment process related to the recent drop of commodity prices - that started in 2011 and accelerated with the sharp drop of energy prices in 2014leading to a level shift in the ToT of many commodity exporters, through the lenses of the historical evidence shown above. Countries experiencing ToT booms (net commodity importers) and busts (net commodity exporters) are explored separately.

The recent ToT bust has been broadly comparable to those in past episodes, although the recent episode has occurred on the back of a ToT short-run boom (as commodity prices recovered from the 2008-09 crisis). For AE commodity exporters, however, the weakening of ToT has been mild relative to previous episodes. Similarly, for those countries that saw their 
ToT improve, the most recent episode has been a mild one relative to past events, suggesting that commodity importers are more diversified today in comparison to the past.

Figure 10. ToT during the recent and past shifts.

(index, demeaned)
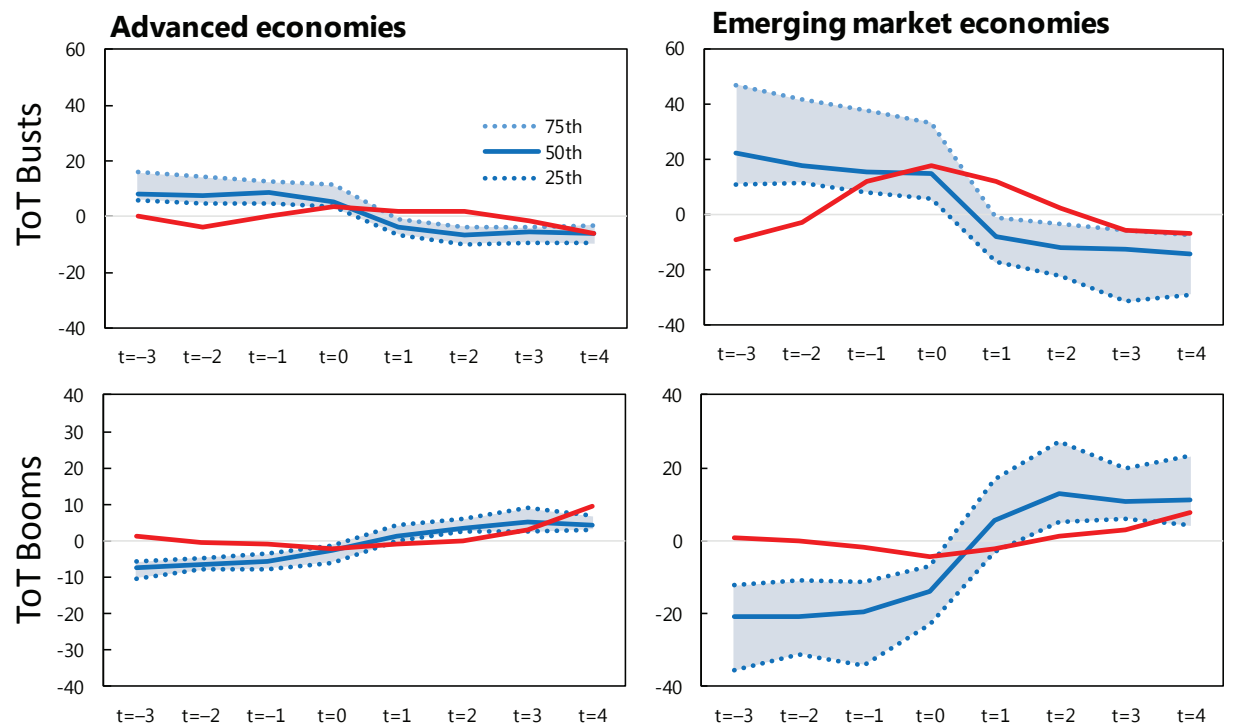

Sources: IMF International Financial Statistics, World Economic Outlook, and authors' calculations.

Current account dynamics in AEs appear to have been dominated by factors other than variations in ToT, while in EMDEs, the ToT shock appears to have been the dominant driver of the current account, displaying a current account weakening of the same order of magnitude of previous episodes (Figure 11). Based on the previously estimated modelwhich allows us to control for the magnitude of the shock - an out-of-sample forecast exercise confirms that the response of current accounts in EMDEs have been broadly consistent with those observed in the past. This has not been the case in AEs, however. 
Figure 11. Current account balances. Recent and past ToT busts (percent of GDP)
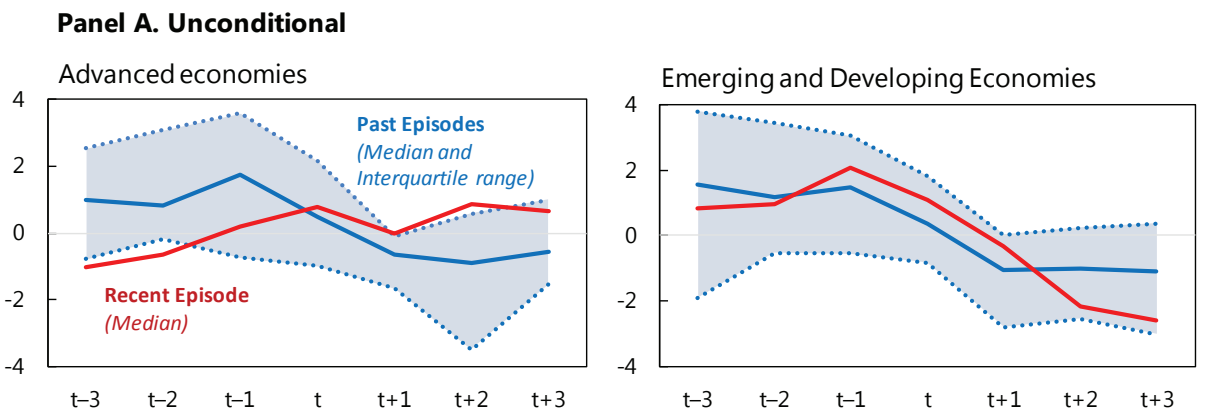

Panel B. Current and Conditional out-of-sample Prediction
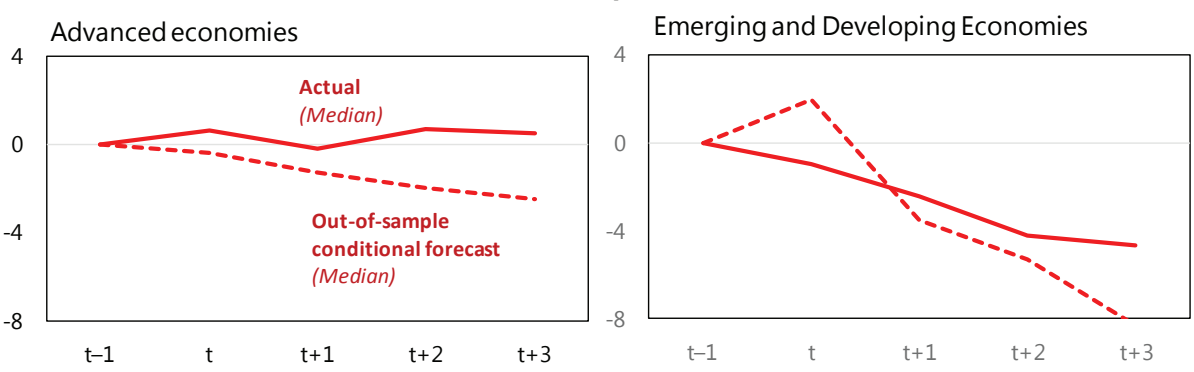

Sources: IMF International Financial Statistics, World Economic Outlook; and authors' estimations.

Finally, Figure 12 explores the role of the exchange flexibility in the recent ToT bust. A simple sample split based on the exchange rate regime indicates that the recent weakening of current accounts in the face of falling ToT has been similar for economies with flexible and fixed exchange rate regimes (left panel). Controlling for the magnitude of the ToT shock, however, reveals a striking difference between the two groups.

Figure 12. Role of exchange rate regime in recent ToT bust episode (current account, in percent GDP, $t-1=0$ )

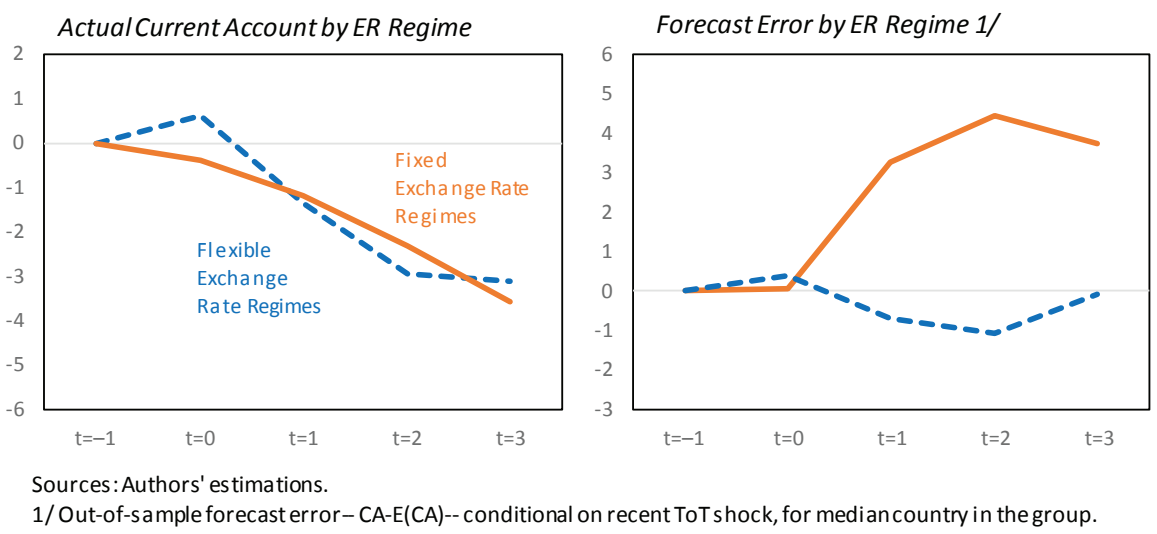

External adjustment in economies with flexible exchange rate regimes has been broadly similar to those observed in countries with similar regimes in the past (as indicated by the muted conditional out-of-sample forecast errors). However, the current account response in economies with fixed exchange rate regimes - which have experienced significantly larger 
ToT busts than those with flexible regimes - has been noticeably different than in the past. As indicated by the conditional out-of-sample forecast errors, economies with pegs have seen stronger current accounts than expected based on the historical responses. This arguably reflects that, faced with sizable drops in their ToT, many of these economies have been unwilling or unable to finance the large current account deficits that would arise had they followed the historical degree of adjustment to large ToT busts.

\section{Conclusions}

The paper identifies episodes of large shifts in ToT during the period 1960-2015, and documents the process of external adjustment. It finds that much of the adjustment to positive (negative) ToT shifts takes place on impact, with current accounts experiencing a contemporaneous strengthening (weakening) of only about $1 / 2$ of the magnitude of the ToT income shock. A full adjustment is visible within 3-4 years. The adjustment appears to reflect primarily a response of domestic demand to the gains (loss) in income associated with the variation in ToT, which is often exacerbated positive output responses to the trade price variations. The latter is particularly strong in net commodity exporting countries. Moreover, and consistent with this finding, import rather than export volumes seem to bear the burden of the adjustment, pointing to an important income effect—and presumably a more muted expenditure switching effect.

These patterns of adjustment are largely symmetric for ToT booms and busts. Although EMDEs are subject to significantly larger ToT variations than AEs, the dynamics are significantly symmetric between the two groups.

Exchange rate flexibility appears to play an important buffering role during booms (inducing increased spending of the ToT income windfall), but less so in ToT busts, possibly pointing to financing constraints in the face of reduced income. Countries tend to use reserve accumulation/decumulation as a tool to mitigate the effect of large shifts in ToT. As expected, large holdings of international reserves buffers do not seem to play a role in the context of ToT booms, but are found to be associated with more gradual external adjustment to ToT busts.

The stylized facts documented in the paper offer a first glance at the process of adjustment to large ToT shocks, and raise a number of questions: what is the channel through which domestic demand adjusts? Does it reflect expectations about the persistence of the shock, or borrowing constraints? What is the role of the public sector and the private sector in the adjustment process? What are the effects of adopting different exchange rate regimes? These are avenues of future research. 


\section{References}

Adler, G. and N. Magud, (2015): "Four Decades of Terms-of-Trade Booms: A Metric of Income Windfall,” Journal of International Money and Finance, Vol 55, July, 162-192.

Agenor, P. R. and J. Aizenman, (2004): "Savings and the Terms of Trade under Borrowing Constraints," Journal of International Economics 63 (2004) 321- 340.

Backus, D.K., (1993): "Interpreting Comovements in the Trade Balance and the Terms of Trade," Journal of International Economics 34, 375-387

Barone S., Descalzi R. y A. Díaz Cafferata (2009): “Terms of Trade Shocks and Current Account Adjustment in Latin American Countries" presentado en XXIV Jornadas Anuales de Economía. Banco Central del Uruguay. October 2009. Montevideo, Uruguay.

Barone, S. and and R. Descalzi, (2010): "Credit Constraints and the Asymmetric Current Account Response to Terms-of-trade Shocks: An Empirical Application to Latin American Countries," Anales Asociacion Argentina de Economia Politica, XLV Reunión Annual.

Baxter, M. (1995): "International Trade and Business cycles", in Grossman, G. and K. Rogoff (eds), Handbook of International Economics, Vol. III, Elsevier Science. B.V., The Netherlands.

Bouakez Hafedh and Kano Takashi, (2008): "Terms of trade and current account fluctuations: The Harberger-Laursen-Metzler effect revisited," Journal of Macroeconomics, Vol. 30, No 1; 260-281.

Cashin, P., and C. J. McDermott (1998): "Terms of Trade Shocks and the Current Account," Working Paper 177, International Monetary Fund.

Edwards, S. (1989): "Temporary Terms-of-Trade Disturbances, the Real Exchange Rate and the Current Account," Economica, 56(223), 343-57.

Hamilton, J. (1994), “Time Series Analysis,” Princeton University Press, Princeton, New Jersey.

Harberger, A. C. (1950): "Currency Depreciation, Income, and the Balance of Trade," Journal of Political Economy, 58(1), 47-60.

International Monetary Fund (IMF), 2016 “External Sector Report”, Washington D.C. Independent Evaluation Office of the International Monetary Fund (2014): "IMF Forecasts: Process, Quality, and Country Perspectives," Washington D.C. 
Kent, C. J., and P. Cashin (2003): "The Response of the Current Account to Terms of Trade Shocks: Persistence Matters,” Working Paper 143, International Monetary Fund.

Laursen, S., and L. Metzler (1950): "Flexible Exchange Rates and the Theory of Employment," Review of Economics and Statistics, 32(4), 281-299.

Mendoza, E. G. (1995): “The Terms of Trade, the Real Exchange Rate, and Economic Fluctuations," International Economic Review, 36(1), 101-37.

Obstfeld, M. (1982): "Aggregate Spending and the Terms of Trade: Is There a LaursenMetzler Effect?," The Quarterly Journal of Economics, 97(2), 251-70.

Obstfelf, M. and K. Rogoff (1995), "The Intertemporal Approach to the Current Account," in Handbook of International Economics, vol.3, North Holland: Amsterdam, Chapter 34.

Obstfeld Maurice and Rogoff Kenneth, (1996): "Foundations of International Economics", MIT Press, Cambridge, Massachusetts.

Ogaki, M., J. Ostry and C. Reinhart, (1996), "Saving Behavior in Low and Middle-Income Countries," IMF Staff Papers 43, pp. 38-71.

Ostry, J. and C. Reinhart, (1992), "Private Savings and Terms of Trade," IMF Staff Papers 32, pp.495-517.

Otto, G. (2003): "Terms of Trade Shocks and the Balance of Trade: There is a HarbergerLaursen-Metzler effect," Journal of International Money and Finance, 22(2), 155-184.

Phillips, S., L. Catão, L. A. Ricci, R. Bems, M. Das, J. di Giovanni, D. F. Unsal, M. Castillo, J. Lee, J. Rodriguez, and M. Vargas, (2013): “The External Balance Assessment (EBA) Methodology," IMF Working Paper 13/272

Sachs, J. D. (1981): "The Current Account and Macroeconomic Adjustment in the 1970s," Brookings Papers on Economic Activity, 12(1), 201-282.

Svensson, L. E. O., and A. Razin (1983): "The Terms of Trade and the Current Account: The Harberger-Laursen-Metzler Effect,” Journal of Political Economy, 91(1), 97-125.

Vegh, Carlos A. (2013): “Open Economy Macroeconomics in Developing Countries,” The MIT Press, Cambridge, Massachusetts. 


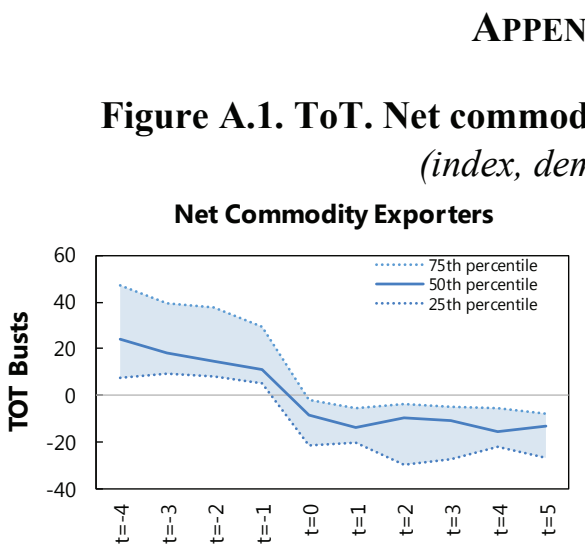

\section{DIX}
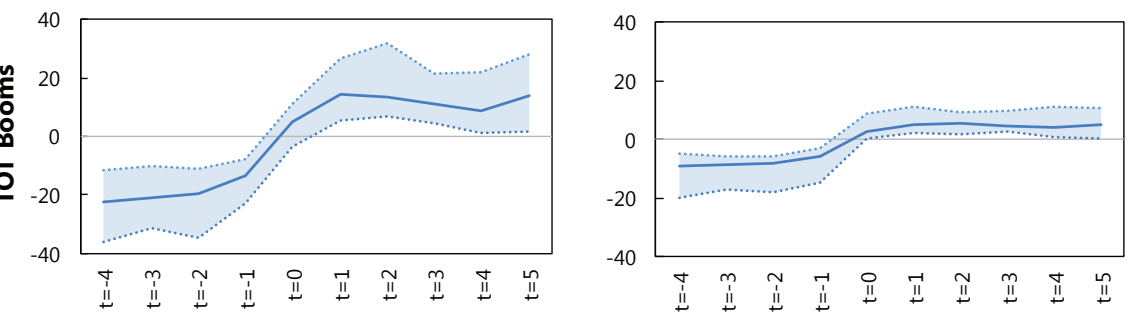

Sources: IMF, World Economic Outlook database; and IMF staff calculations.

Figure A.2. Real exchange rate: Net commodity exporters vs. importers. (index, demeaned)
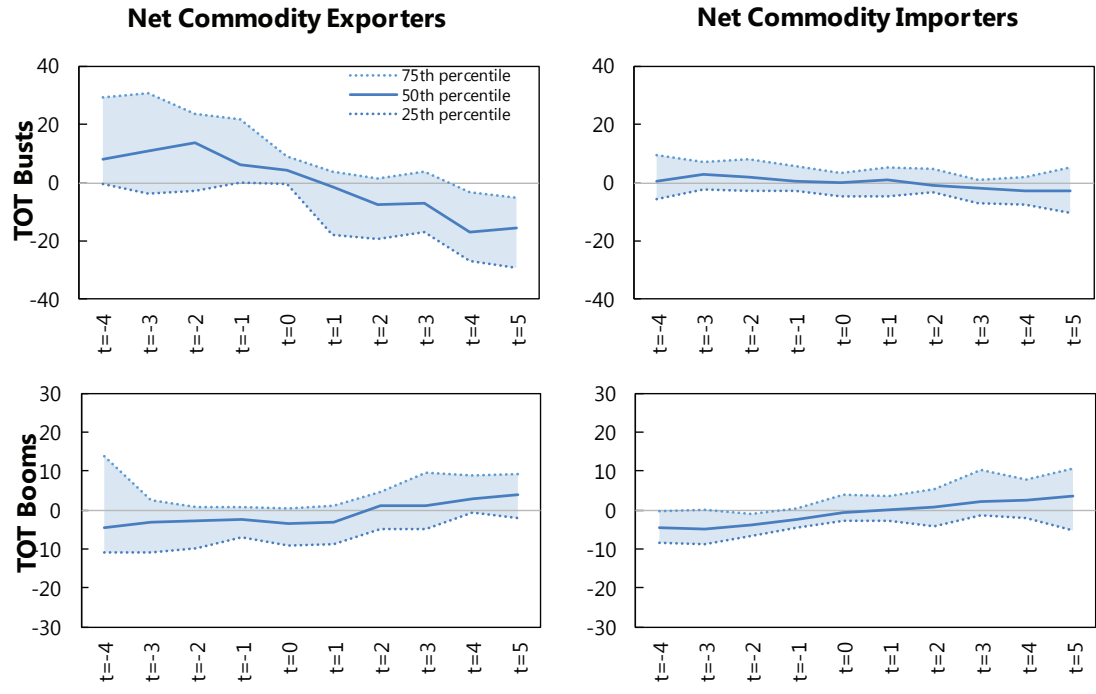

Sources: IMF, World Economic Outlook database; and IMF staff calculations. 
Figure A.3. Current account. Net commodity exporters vs. importers. (percent of GDP, demeaned)
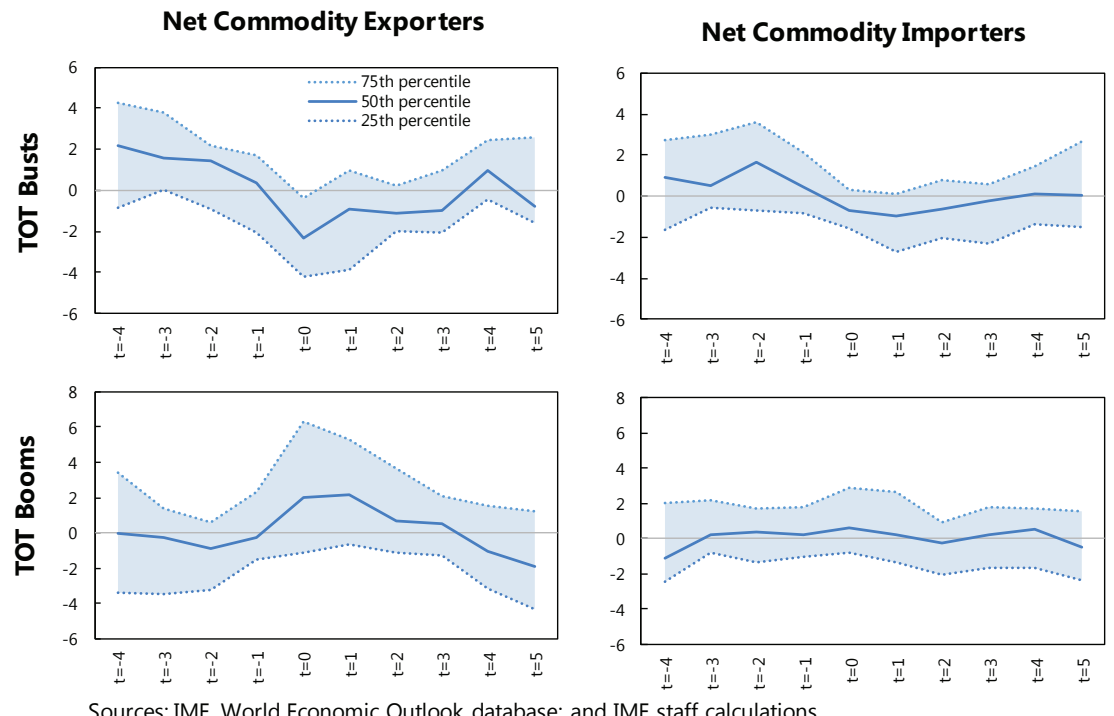

Sources: IMF, World Economic Outlook database; and IMF staff calculations.

Figure A.4. Current account during ToT busts.

Commodity exporters vs. importers: AEs vs. EMs. (percent of GDP, demeaned)

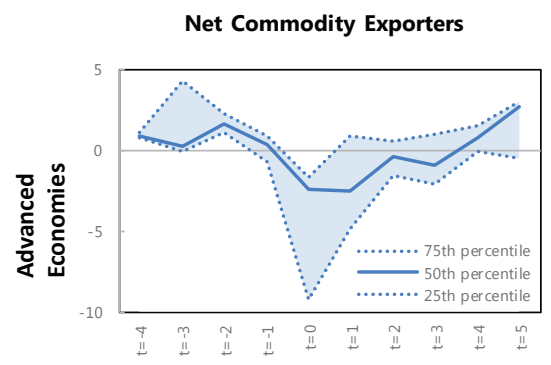

Net Commodity Importers
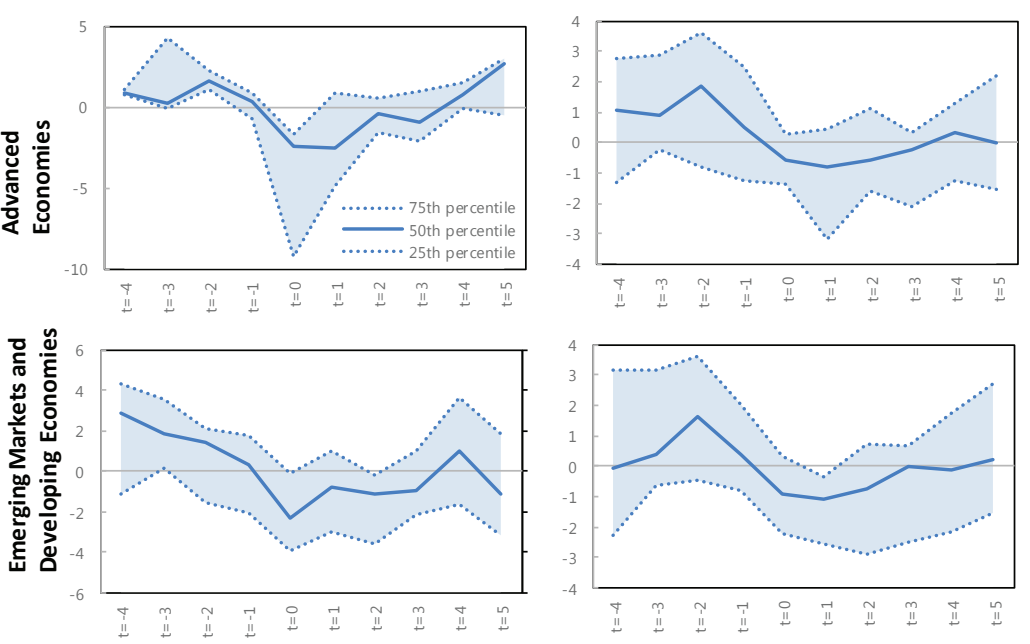
Figure A5. Exports/imports volumes \& prices during ToT busts.

Panel A: volumes
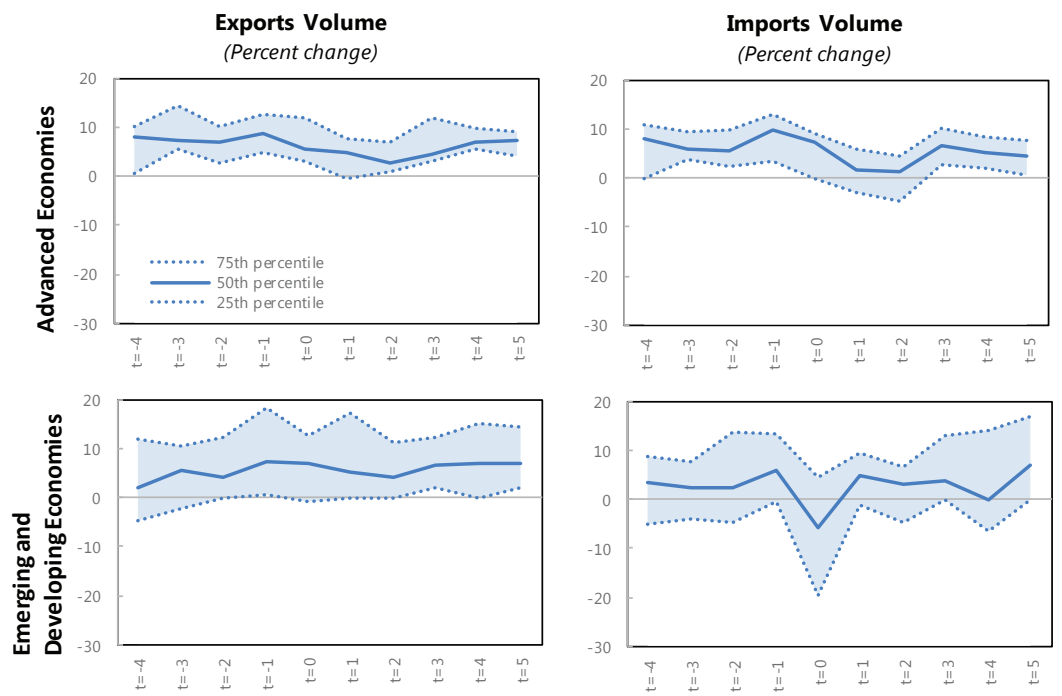

Sources: IMF, World Economic Outlook database; and IMF staff calculations.

Panel B: Prices
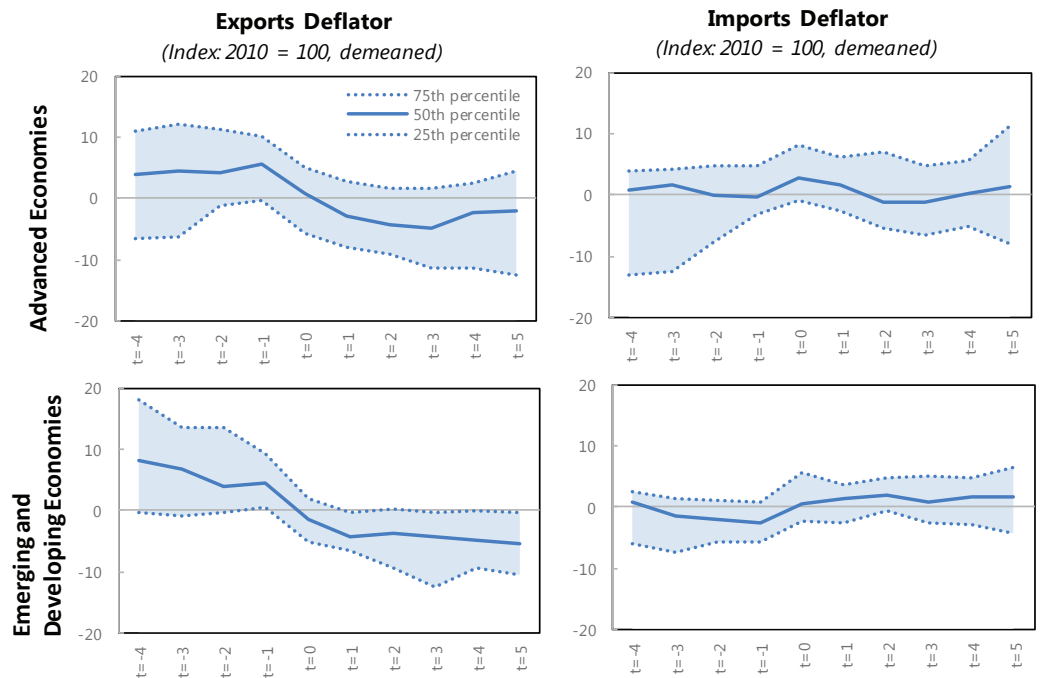

Sources: IMF, World Economic Outlook database; and IMF staff calculations. 
Table A.1. List of identified transitions.

\begin{tabular}{|c|c|c|c|c|c|c|c|c|c|c|c|}
\hline \multicolumn{6}{|c|}{ Terms-of-trade Busts (transitions from High to Low ToT) } & \multicolumn{6}{|c|}{ Terms-of-trade Booms (transitions from Low to High ToT) } \\
\hline & & Low/High & & & Low/High & & & Low/High & & & Low/High \\
\hline Country & $\begin{array}{c}\text { Transition } \\
\text { year 1/ }\end{array}$ & $\begin{array}{l}\text { ToT ratio } \\
\left(\mu_{/} / \mu_{H}\right) 2 /\end{array}$ & Country & $\begin{array}{c}\text { Transition } \\
\text { year } 1 /\end{array}$ & $\begin{array}{l}\text { ToT ratio } \\
\left(\mu_{/} / \mu_{H}\right) 2 /\end{array}$ & Country & $\begin{array}{c}\text { Transition } \\
\text { year 1/ }\end{array}$ & $\begin{array}{l}\text { ToT ratio } \\
\left(\mu_{/} / \mu_{H}\right) 2 /\end{array}$ & Country & $\begin{array}{c}\text { Transition } \\
\text { year 1/ }\end{array}$ & $\begin{array}{l}\text { ToT ratio } \\
\left(\mu_{1} / \mu_{H}\right) 2 /\end{array}$ \\
\hline Albania & 1991 & 0.40 & Mozambique & 1993 & 0.74 & Algeria & 1981 & 0.44 & Israel & 1992 & 0.87 \\
\hline Algeria & 1987 & 0.44 & New Zealand & 1968 & 0.82 & Algeria & 2006 & 0.44 & Jordan & 1989 & 0.69 \\
\hline Argentina & 1982 & 0.62 & New Zealand & 1976 & 0.82 & Argentina & 2008 & 0.62 & Kenya & 1991 & 0.68 \\
\hline Austria & 1998 & 0.93 & Oman & 1987 & 0.43 & Australia & 2007 & 0.63 & Kuwait & 2005 & 0.23 \\
\hline Bangladesh & 1982 & 0.61 & Pakistan & 1991 & 0.63 & Austria & 1986 & 0.93 & Latvia & 2006 & 0.92 \\
\hline Brazil & 1996 & 0.87 & Paraguay & 1980 & 0.66 & Bolivia & 2007 & 0.49 & Malaysia & 1978 & 0.81 \\
\hline Cameroon & 1988 & 0.76 & Portugal & 1981 & 0.86 & Botswana & 1988 & 0.65 & Mali & 2009 & 0.54 \\
\hline Chile & 1976 & 0.52 & Portugal & 2008 & 0.86 & Brazil & 2011 & 0.87 & Mexico & 2001 & 0.73 \\
\hline Colombia & 1988 & 0.70 & Qatar & 1986 & 0.33 & Brunei Darussalam & 2005 & 0.68 & Morocco & 1967 & 0.84 \\
\hline Costa Rica & 1995 & 0.46 & Saudi Arabia & 1986 & 0.43 & Bulgaria & 1986 & 0.73 & Morocco & 1975 & 0.84 \\
\hline Croatia & 1996 & 0.91 & Senegal & 1989 & 0.85 & Cameroon & 1981 & 0.76 & Mozambique & 1985 & 0.74 \\
\hline Cyprus & 1975 & 0.85 & Spain & 1970 & 0.72 & Cameroon & 2006 & 0.76 & Mozambique & 2006 & 0.74 \\
\hline Côte d'Ivoire & 1991 & 0.67 & Sweden & 2002 & 0.93 & Canada & 2005 & 0.87 & Namibia & 2002 & 0.67 \\
\hline Dominican Republic & 1979 & 0.88 & Thailand & 1983 & 0.77 & Chad & 2007 & 0.46 & New Zealand & 1973 & 0.82 \\
\hline Dominican Republic & 2008 & 0.88 & Tunisia & 2002 & 0.69 & Chile & 2007 & 0.52 & New Zealand & 2007 & 0.82 \\
\hline Ecuador & 1987 & 0.53 & Uganda & 1989 & 0.31 & Colombia & 1977 & 0.70 & Nigeria & 2004 & 0.48 \\
\hline Egypt & 1996 & 0.69 & United Arab Emirates & 1987 & 0.54 & Colombia & 2006 & 0.70 & Norway & 2006 & 0.70 \\
\hline El Salvador & 1983 & 0.78 & United Kingdom & 1974 & 0.87 & Croatia & 1994 & 0.91 & Oman & 1981 & 0.43 \\
\hline El Salvador & 2007 & 0.78 & & & & Croatia & 2005 & 0.91 & Oman & 2006 & 0.43 \\
\hline Ethiopia & 1991 & 0.36 & & & & Côte d'Ivoire & 1985 & 0.67 & Panama & 1981 & 0.25 \\
\hline Finland & 1981 & 0.86 & & & & Côte d'Ivoire & 1995 & 0.67 & Peru & 1991 & 0.40 \\
\hline Finland & 2000 & 0.86 & & & & Dominican Republic & 1975 & 0.88 & Portugal & 1987 & 0.86 \\
\hline Germany & 1981 & 0.86 & & & & Dominican Republic & 1982 & 0.88 & Qatar & 1981 & 0.33 \\
\hline Germany & 1992 & 0.86 & & & & Ecuador & 1978 & 0.53 & Qatar & 2004 & 0.33 \\
\hline Greece & 1996 & 0.85 & & & & El Salvador & 1977 & 0.78 & Saudi Arabia & 1981 & 0.43 \\
\hline Guatemala & 2002 & 0.78 & & & & El Salvador & 1980 & 0.78 & Saudi Arabia & 2005 & 0.43 \\
\hline Honduras & 2005 & 0.80 & & & & El Salvador & 1991 & 0.78 & Senegal & 1986 & 0.85 \\
\hline Hungary & 1975 & 0.86 & & & & Ethiopia & 1986 & 0.36 & South Africa & 1981 & 0.36 \\
\hline Iceland & 1982 & 0.86 & & & & Finland & 1988 & 0.86 & Spain & 1990 & 0.72 \\
\hline Iceland & 2009 & 0.86 & & & & Gabon & 2006 & 0.36 & Sri Lanka & 1994 & 0.70 \\
\hline Iran & 1987 & 0.44 & & & & Germany & 1987 & 0.86 & Sweden & 1987 & 0.93 \\
\hline Ireland & 1979 & 0.86 & & & & Ghana & 2007 & 0.35 & Switzerland & 1991 & 0.86 \\
\hline Italy & 1974 & 0.78 & & & & Greece & 1990 & 0.85 & Tunisia & 1980 & 0.69 \\
\hline Jamaica & 1990 & 0.64 & & & & Greece & 1999 & 0.85 & Uganda & 1974 & 0.31 \\
\hline Jordan & 2001 & 0.69 & & & & Guatemala & 1978 & 0.78 & United Arab Emirates & 1980 & 0.54 \\
\hline Korea & 2001 & 0.73 & & & & Guatemala & 1995 & 0.78 & United Arab Emirates & 2006 & 0.54 \\
\hline Latvia & 2001 & 0.92 & & & & Iceland & 1966 & 0.86 & United Kingdom & 1981 & 0.87 \\
\hline Malaysia & 1976 & 0.81 & & & & Iceland & 1988 & 0.86 & Venezuela & 2006 & 0.37 \\
\hline Malaysia & 1983 & 0.81 & & & & Indonesia & 2005 & 0.52 & Vietnam & 1990 & 0.66 \\
\hline Morocco & 1986 & 0.84 & & & & Iran & 1980 & 0.44 & Vietnam & 2008 & 0.66 \\
\hline Morocco & 2011 & 0.84 & & & & Iran & 2006 & 0.44 & & & \\
\hline
\end{tabular}


Table A2. Robustness checks

Excluding large countries and countries with large share in world commodity markets

\begin{tabular}{|c|c|c|c|c|c|c|c|c|c|c|c|c|c|c|c|}
\hline \multirow[b]{3}{*}{ Variables } & \multirow{3}{*}{$\begin{array}{c}\text { Y: } \\
\text { Country sample: }\end{array}$} & \multicolumn{7}{|c|}{ TOT Booms } & \multicolumn{7}{|c|}{ ToT Busts } \\
\hline & & \multicolumn{3}{|c|}{ Current Account } & \multicolumn{4}{|c|}{ Current Account } & \multicolumn{3}{|c|}{ Current Account } & \multicolumn{4}{|c|}{ Current Account } \\
\hline & & $\begin{array}{c}\text { All } \\
\text { countries } \\
(1) \\
\end{array}$ & $\begin{array}{l}\text { AEs } \\
(2) \\
\end{array}$ & $\begin{array}{c}\text { EMDEs } \\
\text { (3) }\end{array}$ & $\begin{array}{c}\text { Flexible ER } \\
\text { Regime } \\
\text { (7) }\end{array}$ & $\begin{array}{c}\text { Fixed ER } \\
\text { Regime } \\
(8) \\
\end{array}$ & $\begin{array}{c}\text { High } \\
\text { Reserves } \\
(9) \\
\end{array}$ & $\begin{array}{c}\text { Low } \\
\text { Reserves } \\
(10) \\
\end{array}$ & $\begin{array}{c}\text { All } \\
\text { countries } \\
(11) \\
\end{array}$ & $\begin{array}{l}\text { AEs } \\
(12) \\
\end{array}$ & $\begin{array}{c}\text { EMDEs } \\
(13)\end{array}$ & $\begin{array}{c}\text { Flexible ER } \\
\text { Regime } \\
(17) \\
\end{array}$ & $\begin{array}{c}\text { Fixed ER } \\
\text { Regime } \\
(18) \\
\end{array}$ & $\begin{array}{c}\text { High } \\
\text { Reserves } \\
(19) \\
\end{array}$ & $\begin{array}{c}\text { Low } \\
\text { Reserves } \\
(20) \\
\end{array}$ \\
\hline TOT shock & & $\begin{array}{r}0.405 * * * \\
(0.027)\end{array}$ & $\begin{array}{r}0.558^{* * *} \\
(0.090)\end{array}$ & $\begin{array}{r}0.394 * * * \\
(0.031)\end{array}$ & $\begin{array}{r}0.259 * * * \\
(0.063)\end{array}$ & $\begin{array}{r}0.330 * * * \\
(0.030)\end{array}$ & $\begin{array}{r}0.470 * * * \\
(0.032)\end{array}$ & $\begin{array}{r}0.376^{* * *} \\
(0.058)\end{array}$ & $\begin{array}{r}0.510^{* * *} \\
(0.051)\end{array}$ & $\begin{array}{r}0.594 * * * \\
(0.106)\end{array}$ & $\begin{array}{r}0.502 * * * \\
(0.059)\end{array}$ & $\begin{array}{c}0.272^{* *} \\
(0.113)\end{array}$ & $\begin{array}{r}0.236 * * * \\
(0.040)\end{array}$ & $\begin{array}{r}0.716 * * * \\
(0.083)\end{array}$ & $\begin{array}{r}0.156 * * * \\
(0.039)\end{array}$ \\
\hline L.TOT shock & & $\begin{array}{r}0.091^{* * *} \\
(0.029)\end{array}$ & & $\begin{array}{c}0.072^{* *} \\
(0.033)\end{array}$ & $\begin{array}{r}-0.132^{* *} \\
(0.053)\end{array}$ & $\begin{array}{r}0.115^{* * *} \\
(0.030)\end{array}$ & $\begin{array}{r}0.049 \\
(0.035)\end{array}$ & & & & & $\begin{array}{c}0.231^{* *} \\
(0.110)\end{array}$ & $\begin{array}{r}0.118^{* * *} \\
(0.040)\end{array}$ & & \\
\hline L2.TOT shock & & $\begin{array}{r}0.092^{* * *} \\
(0.028)\end{array}$ & & $\begin{array}{c}0.077^{* *} \\
(0.032)\end{array}$ & & $\begin{array}{r}0.118^{* * *} \\
(0.030)\end{array}$ & & & & & & & & & \\
\hline Constant & & $\begin{array}{r}-0.647^{* * * *} \\
(0.193)\end{array}$ & $\begin{array}{r}-0.698 * * * \\
(0.204)\end{array}$ & $\begin{array}{r}-0.518^{* *} \\
(0.249)\end{array}$ & $\begin{array}{c}-0.402 \\
(0.290)\end{array}$ & $\begin{array}{r}-1.135^{* * * *} \\
(0.230)\end{array}$ & $\begin{array}{c}-0.437^{*} \\
(0.229)\end{array}$ & $\begin{array}{r}-0.426 \\
(0.363)\end{array}$ & $\begin{array}{c}-0.373^{*} \\
(0.191)\end{array}$ & $\begin{array}{r}-0.727^{* *} \\
(0.308)\end{array}$ & $\begin{array}{r}-0.264 \\
(0.253)\end{array}$ & $\begin{array}{r}-0.352 \\
(0.300)\end{array}$ & $\begin{array}{r}-2.244 * * * \\
(0.225)\end{array}$ & $\begin{array}{r}-0.002 \\
(0.357)\end{array}$ & $\begin{array}{r}-2.301^{* * *} \\
(0.220)\end{array}$ \\
\hline Number of observations & & 645 & 169 & 494 & 175 & 389 & 363 & 321 & 524 & 162 & 362 & 126 & 320 & 237 & 246 \\
\hline Number of countries & & 74 & 18 & 57 & 18 & 45 & 37 & 34 & 56 & 18 & 38 & 15 & 34 & 25 & 26 \\
\hline Adjusted R2 & & 0.35 & 0.00 & 0.65 & 0.41 & 0.60 & 0.05 & 0.18 & 0.84 & 0.11 & 0.72 & 0.74 & 0.75 & 0.96 & 0.03 \\
\hline Sargan $P$ value & & 0.000 & 0.000 & 0.000 & 0.000 & 0.000 & 0.000 & 0.000 & 0.000 & 0.000 & 0.000 & 0.000 & 0.000 & 0.000 & 0.000 \\
\hline Sargan Test & & 727.2 & 188.6 & 558.2 & 160.6 & 367.7 & 347.2 & 308.4 & 433.6 & 160.8 & 302.6 & 133.7 & 365.5 & 207.3 & 252 \\
\hline
\end{tabular}

\section{Large ToT shocks only (>20\%)}

\begin{tabular}{|c|c|c|c|c|c|c|c|c|}
\hline \multirow[b]{3}{*}{ Variables } & \multirow[b]{3}{*}{ Country sample: } & \multicolumn{7}{|c|}{ TOT Booms } \\
\hline & & \multicolumn{3}{|c|}{ Current Account } & \multicolumn{4}{|c|}{ Current Account } \\
\hline & & $\begin{array}{c}\text { All } \\
\text { countries } \\
\text { (1) } \\
\end{array}$ & $\begin{array}{l}\text { AEs } \\
(2) \\
\end{array}$ & $\begin{array}{c}\text { EMDEs } \\
\text { (3) }\end{array}$ & $\begin{array}{c}\text { Flexible ER } \\
\text { Regime } \\
(7) \\
\end{array}$ & $\begin{array}{l}\text { Fixed ER } \\
\text { Regime } \\
(8) \\
\end{array}$ & $\begin{array}{c}\text { High } \\
\text { Reserves } \\
(9) \\
\end{array}$ & $\begin{array}{c}\text { Low } \\
\text { Reserves } \\
(10) \\
\end{array}$ \\
\hline L.Y & & $\begin{array}{r}0.626 * * * \\
(0.025)\end{array}$ & $\begin{array}{r}0.960 * * * \\
(0.028)\end{array}$ & $\begin{array}{r}0.627 * * * \\
(0.026)\end{array}$ & $\begin{array}{r}0.736^{* * *} \\
(0.056)\end{array}$ & $\begin{array}{r}0.561^{* * *} \\
(0.031)\end{array}$ & $\begin{array}{r}0.578^{* * *} \\
(0.035)\end{array}$ & $\begin{array}{r}0.822^{* * *} \\
(0.033)\end{array}$ \\
\hline TOT shock & & $\begin{array}{r}0.437 * * * \\
(0.030)\end{array}$ & $\begin{array}{r}0.459 * * * \\
(0.082)\end{array}$ & $\begin{array}{r}0.434 * * * \\
(0.031)\end{array}$ & $\begin{array}{r}0.250^{* * * *} \\
(0.067)\end{array}$ & $\begin{array}{r}0.382^{* * * *} \\
(0.036)\end{array}$ & $\begin{array}{r}0.498^{* * *} \\
(0.034)\end{array}$ & $\begin{array}{r}0.394 * * * \\
(0.068)\end{array}$ \\
\hline L.TOT shock & & $\begin{array}{r}0.110^{* * * *} \\
(0.032)\end{array}$ & & $\begin{array}{r}0.108 * * * \\
(0.033)\end{array}$ & $\begin{array}{r}-0.183^{* * *} \\
(0.056)\end{array}$ & $\begin{array}{r}0.143 * * * \\
(0.037)\end{array}$ & $\begin{array}{r}0.100 * * * \\
(0.035)\end{array}$ & \\
\hline L2.TOT shock & & $\begin{array}{r}0.088^{* * * *} \\
(0.032)\end{array}$ & & $\begin{array}{r}0.085 * * * \\
(0.033)\end{array}$ & & $\begin{array}{r}0.114^{* * *} \\
(0.036)\end{array}$ & & \\
\hline Constant & & $\begin{array}{r}-0.283 \\
(0.260)\end{array}$ & $\begin{array}{r}-0.744 * * * \\
(0.265)\end{array}$ & $\begin{array}{r}-0.266 \\
(0.274)\end{array}$ & $\begin{array}{r}0.020 \\
(0.351)\end{array}$ & $\begin{array}{r}-0.926^{* * *} \\
(0.352)\end{array}$ & $\begin{array}{r}-0.073 \\
(0.307)\end{array}$ & $\begin{array}{r}-0.301 \\
(0.504)\end{array}$ \\
\hline Number of observations & & 496 & 30 & 469 & 140 & 262 & 294 & 230 \\
\hline Number of countries & & 56 & 3 & 53 & 14 & 30 & 30 & 24 \\
\hline Adjusted R2 & & 0.36 & 0.43 & 0.37 & 0.21 & 0.77 & 0.26 & 0.23 \\
\hline Sargan P value & & 0.000 & 0.244 & 0.000 & 0.000 & 0.000 & 0.000 & 0.000 \\
\hline Sargan Test & & 561.1 & 31.67 & 532.5 & 124.7 & 253.6 & 298.7 & 222.4 \\
\hline
\end{tabular}

\begin{tabular}{|c|c|c|c|c|c|c|}
\hline \multicolumn{7}{|c|}{ ToT Busts } \\
\hline \multicolumn{3}{|c|}{ Current Account } & \multicolumn{4}{|c|}{ Current Account } \\
\hline $\begin{array}{c}\text { All } \\
\text { countries } \\
(11) \\
\end{array}$ & $\begin{array}{l}\text { AEs } \\
(12) \\
\end{array}$ & $\begin{array}{c}\text { EMDEs } \\
(13)\end{array}$ & $\begin{array}{c}\text { Flexible ER } \\
\text { Regime } \\
(17)\end{array}$ & $\begin{array}{c}\text { Fixed ER } \\
\text { Regime } \\
(18) \\
\end{array}$ & $\begin{array}{c}\text { High } \\
\text { Reserves } \\
(19) \\
\end{array}$ & $\begin{array}{c}\text { Low } \\
\text { Reserves } \\
(20)\end{array}$ \\
\hline $\begin{array}{r}0.745^{* * *} \\
(0.024)\end{array}$ & $\begin{array}{r}0.533 * * * \\
(0.149)\end{array}$ & $\begin{array}{r}0.752^{* * *} \\
(0.025)\end{array}$ & $\begin{array}{r}0.543^{* * *} \\
(0.092)\end{array}$ & $\begin{array}{r}0.387 * * * \\
(0.054)\end{array}$ & $\begin{array}{r}0.802^{* * * *} \\
(0.030)\end{array}$ & $\begin{array}{r}0.219^{* * *} \\
(0.081)\end{array}$ \\
\hline $0.517^{* * *}$ & $0.780^{* *}$ & $0.508 * * *$ & $0.234^{* *}$ & $0.252^{* * *}$ & $0.697 * * *$ & $0.157 * * *$ \\
\hline$(0.061)$ & $(0.315)$ & $(0.063)$ & $\begin{array}{r}(0.108) \\
-0.003 \\
(0.104)\end{array}$ & $\begin{array}{r}(0.050) \\
0.231^{* * *} \\
(0.047)\end{array}$ & $(0.093)$ & $(0.046)$ \\
\hline $\begin{array}{r}0.054 \\
(0.280)\end{array}$ & $\begin{array}{r}0.627 \\
(0.543)\end{array}$ & $\begin{array}{r}0.002 \\
(0.302)\end{array}$ & $\begin{array}{r}-0.523 \\
(0.355)\end{array}$ & $\begin{array}{r}-1.468 * * * \\
(0.271)\end{array}$ & $\begin{array}{r}0.494 \\
(0.494)\end{array}$ & $\begin{array}{r}-2.103^{* * *} \\
(0.299)\end{array}$ \\
\hline 325 & 29 & 296 & 84 & 178 & 163 & 139 \\
\hline 34 & 3 & 31 & 10 & 18 & 17 & 14 \\
\hline 0.56 & 0.69 & 0.57 & 0.90 & 0.07 & 0.45 & 0.04 \\
\hline 0.000 & 0.289 & 0.000 & 0.003 & 0.000 & 0.000 & 0.000 \\
\hline 269.8 & 29.49 & 247.7 & 86.32 & 195.4 & 147.2 & 125.8 \\
\hline
\end{tabular}

Sources: authors' estimations.

1 Standard errors in parentheses. $* * * p<0.01,{ }^{* *} p<0.05, * p<0.1$ 
Table A2. Robustness checks

Controlling for global financial conditions

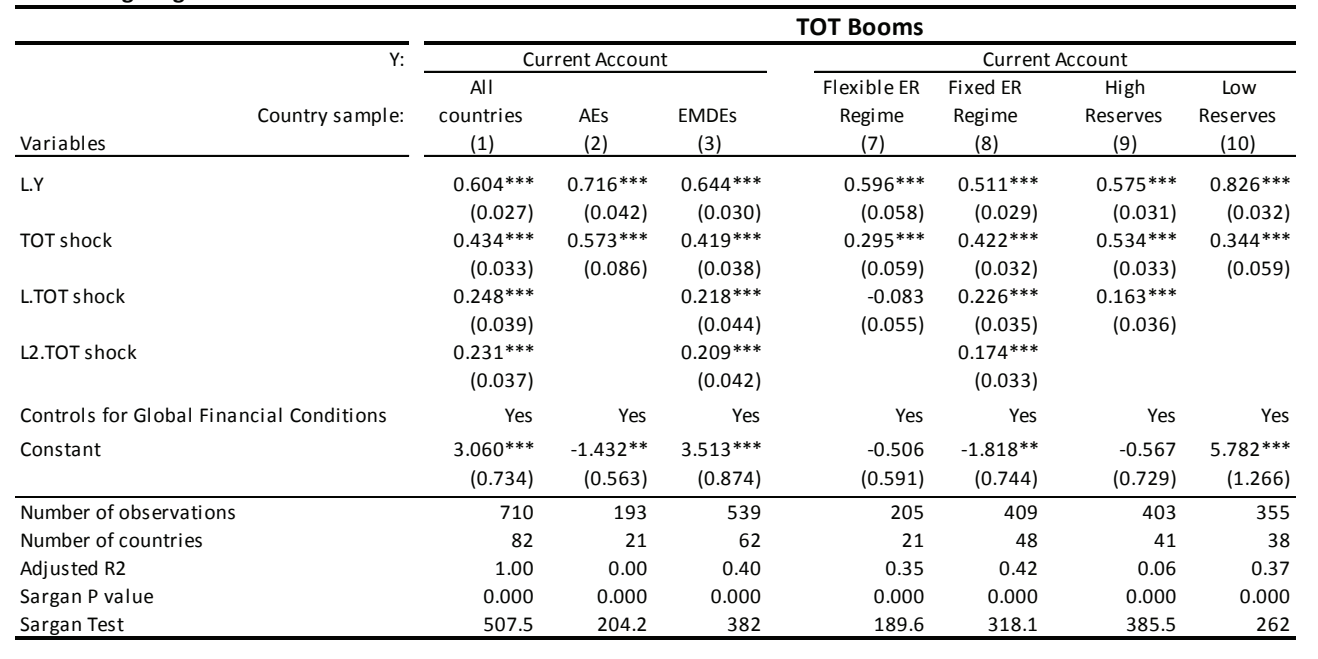

Controlling for global financial conditions and external demand

\begin{tabular}{|c|c|c|c|c|c|c|c|}
\hline \multirow[b]{3}{*}{ Country sample: } & \multicolumn{7}{|c|}{ TOT Booms } \\
\hline & \multicolumn{3}{|c|}{ Current Account } & \multicolumn{4}{|c|}{ Current Account } \\
\hline & $\begin{array}{c}\text { All } \\
\text { countries } \\
(1) \\
\end{array}$ & $\begin{array}{l}\text { AEs } \\
(2) \\
\end{array}$ & $\begin{array}{c}\text { EMDEs } \\
\text { (3) }\end{array}$ & $\begin{array}{c}\text { Flexible ER } \\
\text { Regime } \\
\text { (7) }\end{array}$ & $\begin{array}{l}\text { Fixed ER } \\
\text { Regime } \\
(8) \\
\end{array}$ & $\begin{array}{c}\text { High } \\
\text { Reserves } \\
(9) \\
\end{array}$ & $\begin{array}{c}\text { Low } \\
\text { Reserves } \\
(10) \\
\end{array}$ \\
\hline L.Y & $\begin{array}{r}0.601 * * * \\
(0.028)\end{array}$ & $\begin{array}{r}0.747 * * * \\
(0.045)\end{array}$ & $\begin{array}{r}0.648 * * * \\
(0.031)\end{array}$ & $\begin{array}{r}0.587^{* * *} \\
(0.059)\end{array}$ & $\begin{array}{r}0.503 * * * \\
(0.032)\end{array}$ & $\begin{array}{r}0.579 * * * \\
(0.031)\end{array}$ & $\begin{array}{r}0.863^{* * *} \\
(0.037)\end{array}$ \\
\hline TOT shock & $\begin{array}{r}0.398^{* * * *} \\
(0.036)\end{array}$ & $\begin{array}{r}0.898^{* * *} \\
(0.109)\end{array}$ & $\begin{array}{r}0.378 * * * \\
(0.041)\end{array}$ & $\begin{array}{r}0.285^{* * *} \\
(0.060)\end{array}$ & $\begin{array}{r}0.364 * * * \\
(0.038)\end{array}$ & $\begin{array}{r}0.545 * * * \\
(0.036)\end{array}$ & $\begin{array}{r}0.263^{* * *} \\
(0.069)\end{array}$ \\
\hline L.TOT shock & $\begin{array}{r}0.294 * * * \\
(0.043)\end{array}$ & & $\begin{array}{r}0.260 * * * \\
(0.048)\end{array}$ & $\begin{array}{r}-0.071 \\
(0.056)\end{array}$ & $\begin{array}{r}0.253^{* * *} \\
(0.039)\end{array}$ & $\begin{array}{r}0.153^{* * *} \\
(0.037)\end{array}$ & \\
\hline L2.TOT shock & $\begin{array}{r}0.264 * * * \\
(0.040)\end{array}$ & & $\begin{array}{r}0.239 * * * \\
(0.045)\end{array}$ & & $\begin{array}{r}0.191^{* * *} \\
(0.037)\end{array}$ & & \\
\hline Controls for Global Financial Conditions & Yes & Yes & Yes & Yes & Yes & Yes & Yes \\
\hline Control for External Demand & Yes & Yes & Yes & Yes & Yes & Yes & Yes \\
\hline Constant & -2.595 & $7.358^{* * *}$ & $-3.452^{*}$ & -1.817 & $-9.189 * * *$ & 0.769 & $-9.213^{* * *}$ \\
\hline & -1.775 & -1.637 & -2.031 & -1.446 & -2.102 & -1.638 & -3.561 \\
\hline Number of observations & 710 & 191 & 539 & 205 & 409 & 402 & 355 \\
\hline Number of countries & 82 & 21 & 62 & 21 & 48 & 41 & 38 \\
\hline Adjusted R2 & 0.07 & 0.00 & 0.24 & 0.30 & 0.47 & 0.07 & 0.02 \\
\hline Sargan $P$ value & 0.000 & 0.000 & 0.000 & 0.000 & 0.000 & 0.000 & 0.000 \\
\hline Sargan Test & 448.4 & 136.9 & 330.7 & 187.4 & 252.3 & 386.5 & 185.1 \\
\hline
\end{tabular}

Sources: authors' estimations.

1 / Standard errors in parentheses. ${ }^{* * *} p<0.01, * * p<0.05, * p<0.1$

\begin{tabular}{|c|c|c|c|c|c|c|}
\hline \multicolumn{7}{|c|}{ Tot Busts } \\
\hline \multicolumn{3}{|c|}{ Current Account } & \multicolumn{4}{|c|}{ Current Account } \\
\hline $\begin{array}{c}\text { All } \\
\text { countries } \\
(11) \\
\end{array}$ & $\begin{array}{l}\text { AEs } \\
(12) \\
\end{array}$ & $\begin{array}{c}\text { EMDEs } \\
(13)\end{array}$ & $\begin{array}{c}\text { Flexible ER } \\
\text { Regime } \\
(17) \\
\end{array}$ & $\begin{array}{c}\text { Fixed ER } \\
\text { Regime } \\
(18) \\
\end{array}$ & $\begin{array}{c}\text { High } \\
\text { Reserves } \\
(19) \\
\end{array}$ & $\begin{array}{c}\text { Low } \\
\text { Reserves } \\
(20)\end{array}$ \\
\hline $\begin{array}{r}0.667^{* * *} \\
(0.029)\end{array}$ & $\begin{array}{r}0.602^{* * * *} \\
(0.066)\end{array}$ & $\begin{array}{r}0.746^{* * *} \\
(0.029)\end{array}$ & $\begin{array}{r}0.656 * * * \\
(0.064)\end{array}$ & $\begin{array}{r}0.265 * * * \\
(0.050)\end{array}$ & $\begin{array}{r}0.785^{* * *} \\
(0.036)\end{array}$ & $\begin{array}{r}0.143^{* *} \\
(0.063)\end{array}$ \\
\hline $\begin{array}{r}0.510^{* * *} \\
(0.048)\end{array}$ & $\begin{array}{r}0.629 * * * \\
(0.098)\end{array}$ & $\begin{array}{r}0.514^{* * *} \\
(0.058)\end{array}$ & $\begin{array}{r}0.329^{* * *} \\
(0.089) \\
0.118 \\
(0.085)\end{array}$ & $\begin{array}{r}0.246^{* * *} \\
(0.044) \\
0.212^{* * *} \\
(0.041)\end{array}$ & $\begin{array}{r}0.689 * * * \\
(0.080)\end{array}$ & $\begin{array}{r}0.197 * * * \\
(0.039)\end{array}$ \\
\hline Yes & Yes & Yes & Yes & Yes es & Yes & Yes \\
\hline $\begin{array}{r}1.155 \\
(1.038)\end{array}$ & $\begin{array}{c}-0.933 \\
(0.638)\end{array}$ & $\begin{array}{r}1.848 \\
(1.496)\end{array}$ & $\begin{array}{c}-0.592 \\
(0.569)\end{array}$ & $\begin{array}{l}1.001^{*} \\
(0.568)\end{array}$ & $\begin{array}{c}-0.832 \\
(1.550)\end{array}$ & $\begin{array}{r}0.147 \\
(0.489)\end{array}$ \\
\hline 584 & 192 & 392 & 166 & 330 & 267 & 276 \\
\hline 62 & 21 & 41 & 19 & 35 & 28 & 29 \\
\hline 0.84 & 0.10 & 0.80 & 0.56 & 0.14 & 0.77 & 0.98 \\
\hline 0.000 & 0.000 & 0.000 & 0.000 & 0.000 & 0.000 & 0.000 \\
\hline 470.1 & 177.9 & 313 & 177 & 287.6 & 223.2 & 213 \\
\hline
\end{tabular}

\begin{tabular}{|c|c|c|c|c|c|c|}
\hline \multicolumn{7}{|c|}{ ToT Busts } \\
\hline \multicolumn{3}{|c|}{ Current Account } & \multicolumn{4}{|c|}{ Current Account } \\
\hline $\begin{array}{c}\text { All } \\
\text { countries } \\
(11) \\
\end{array}$ & $\begin{array}{l}\text { AEs } \\
(12) \\
\end{array}$ & $\begin{array}{c}\text { EMDEs } \\
(13)\end{array}$ & $\begin{array}{c}\text { Flexible ER } \\
\text { Regime } \\
(17) \\
\end{array}$ & $\begin{array}{c}\text { Fixed ER } \\
\text { Regime } \\
(18)\end{array}$ & $\begin{array}{c}\text { High } \\
\text { Reserves } \\
(19)\end{array}$ & $\begin{array}{c}\text { Low } \\
\text { Reserves } \\
(20)\end{array}$ \\
\hline $\begin{array}{r}0.677^{* * *} \\
(0.031)\end{array}$ & $\begin{array}{r}0.688^{* * *} \\
(0.072)\end{array}$ & $\begin{array}{r}0.746^{* * *} \\
(0.029)\end{array}$ & $\begin{array}{r}0.640^{* * *} \\
(0.067)\end{array}$ & $\begin{array}{r}0.285^{* * *} \\
(0.052)\end{array}$ & $\begin{array}{c}0.776^{* * *}{ }^{*} \\
(0.039)\end{array}$ & $\begin{array}{r}0.107 \\
(0.066\end{array}$ \\
\hline $0.521^{* * *}$ & $0.697 * * *$ & $0.513 * * *$ & $0.320^{* * *}$ & $0.249 * * *$ & $0.684^{* * *}$ & $0.194 * * *$ \\
\hline$(0.051)$ & $(0.103)$ & $(0.058)$ & $(0.090)$ & $(0.044)$ & $(0.081)$ & $(0.041)$ \\
\hline & & & 0.114 & $0.207^{* * *}$ & & \\
\hline & & & $(0.085)$ & $(0.042)$ & & \\
\hline Yes & Yes & Yes & Yes & Yes & Yes & Yes \\
\hline Yes & Yes & Yes & Yes & Yes & Yes & Yes \\
\hline $7.680^{* * *}$ & $4.448^{* *}$ & 1.669 & -1.492 & $3.660^{* *}$ & -3.032 & $-2.645 * * *$ \\
\hline-2.519 & -1.771 & -3.173 & -1.301 & -1.436 & -3.45 & -1.183 \\
\hline 584 & 192 & 392 & 166 & 330 & 267 & 276 \\
\hline 62 & 21 & 41 & 19 & 35 & 28 & 29 \\
\hline 0.77 & 0.50 & 0.78 & 0.58 & 0.25 & 0.64 & 0.46 \\
\hline 0.000 & 0.000 & 0.000 & 0.000 & 0.000 & 0.000 & 0.000 \\
\hline 419.5 & 158.1 & 313.3 & 176.1 & 274.1 & 220.4 & 193.1 \\
\hline
\end{tabular}

